\title{
Effect of $\mathrm{BaCO}_{3}$ reactivity and mixing procedure on sulfate-resistant cement performance
}

\author{
P.M. Carmona-Quiroga ${ }^{\text {a, }}$, C. Mota-Heredia ${ }^{\mathrm{a}}$, M. Torres-Carrasco ${ }^{\mathrm{b}, \mathrm{c}}$, J.F. Fernández $^{\mathrm{b}}$, M. \\ T. Blanco-Varela ${ }^{a}$ \\ a Instituto de Ciencias de la Construcción Eduardo Torroja (IETcc-CSIC), Serrano Galvache 4, 28033, Madrid, Spain \\ ${ }^{\mathrm{b}}$ Electroceramic Department, Instituto de Cerámica y Vidrio, CSIC, Kelsen 5, 28049, Madrid, Spain \\ ${ }^{\mathrm{c}}$ Materials Science and Engineering Department, IAAB, Universidad Carlos III de Madrid, Avda. Universidad 30, 28911, Leganés, Madrid, Spain
}

\section{A R T I C L E I N F O}

\section{Keywords:}

Sulfate resistant cements

Cement paste

$\mathrm{BaCO}_{3}$

Electrodeposition

Fineness

Ettringite

\begin{abstract}
A B S T R A C T
The present study focuses on exploring the effects of reactivity and degree of dispersion of $\mathrm{BaCO}_{3}$ additions in the manufacture of sulfate-resistant OPC cements. A new electrochemical deposition method is attempted to effectively disperse $\mathrm{BaCO}_{3}$ particles (studying two different materials with particle size: $\mathrm{D}_{50}=11.45$ and $2.37 \mu \mathrm{m}$ ) on cement to enhance their reactivity and favour sulfate immobilisation in the form of $\mathrm{BaSO}_{4}$. The barium carbonate additions, particularly the finest, activate cement hydration to a greater extent. Electrodeposition is also observed to improve early age reactivity $(2 \mathrm{~d}-7 \mathrm{~d})$ in fine $\mathrm{BaCO}_{3}$. Cement paste bearing 15 wt $\% \mathrm{BaCO}_{3}$ is more resistant to sulfate attack by a $5 \%(\mathrm{w} / \mathrm{v})$ solution of $\mathrm{Na}_{2} \mathrm{SO}_{4}\left(180 \mathrm{~d}\right.$ at $\left.23{ }^{\circ} \mathrm{C}\right)$ than a commercial sulfate-resistant cement, although secondary ettringite and gypsum precipitated in all cases.
\end{abstract}

\section{Introduction}

Sulfate-resistant cements are manufactured in the absence or with very low proportions of $\mathrm{C}_{3} \mathrm{~A}(0-5 \%$ in CEM I-SR [1]) to prevent the detrimental precipitation of ettringite $\left(3 \mathrm{CaO} \cdot \mathrm{Al}_{2} \mathrm{O}_{3} \cdot 3 \mathrm{CaSO}_{4} \cdot 32 \mathrm{H}_{2} \mathrm{O}\right)$. Paradoxically, more gypsum may precipitate in such cements because more $\mathrm{Ca}(\mathrm{OH})_{2}$ is formed with higher amounts of $\mathrm{C}_{3} \mathrm{~S}$. Natural pozzolans as well as pozzolanic industrial by-products such as fly ash and ground granulated furnace slag (CEM III-SR and CEM IV-SR) [1] are consequently added to cement clinker to compete for the calcium or $\mathrm{Ca}(\mathrm{OH})_{2}$ needed for ettringite precipitation or gypsum formation, respectively [2, 3]. The aforementioned supplementary cementitious materials (SCMs) may also be used to control thaumasite $\left(\mathrm{CaSiO}_{3} \cdot \mathrm{CaCO}_{3} \cdot \mathrm{CaSO}_{4} \cdot 15 \mathrm{H}_{2} \mathrm{O}\right)$ precipitation [4].

The pursuit of innovative, 'one size fits all' solutions to counteract sulfate attack in special applications have led to some promising results with barium compounds. Thermodynamic analysis $[5,6]$ corroborated by experimental studies [7-11] have shown that the barite $\left(\mathrm{BaSO}_{4}\right)$ formation induces immobilisation of internal or external sulfates and therefore hinders the precipitation of the three aforementioned salts.

Although witherite $\left(\mathrm{BaCO}_{3}\right)$ was identified as early as the forties to increase cement resistance to sulfate attack [12], research in the area has only been undertaken in the last 7 years [7-11]. The reasons for such belated interest may be associated with the limited supply of witherite in certain regions and the widely extended use of mineral admixtures. However, in China, the world's leading producer of cement and witherite and other regions were this mineral is readily available this line of research may be promising specially if industrial by-products are apart from the construction sites. Use of barium compounds may have also constrained by their toxicity. Virtually non-bioaccessible, non-soluble $\mathrm{BaSO}_{4}\left(2.210^{-3} \mathrm{~g} / \mathrm{L}\right.$ in water at $\left.18{ }^{\circ} \mathrm{C}\right)$ [13] is not toxic, unlike $\mathrm{BaCO}_{3}$ whose solubility $\left(2210^{-3} \mathrm{~g} / \mathrm{L}\right.$ at $\left.25^{\circ} \mathrm{C}\right)$ is slightly higher than that of $\mathrm{CaCO}_{3}\left(1410^{-3} \mathrm{~g} / \mathrm{L}\right.$ at $\left.25^{\circ} \mathrm{C}\right)$. However, $\mathrm{Ba}^{2+}$ is normally unable to migrate into the groundwater given its ability to combine with the sulfates and carbonates in the soils. Nonetheless, barium compounds may dissolve and migrate in acidic soils $[14,15]$.

Inconsistent results reported on the performance of Ba-compound additions in the short number of studies conducted to date have further contributed to misgivings around their use. Wen et al. [11] found that sulfate resistance increases with $\leq 4 \mathrm{wt} \% \mathrm{Ba}(\mathrm{OH})_{2}$ additions to mortars made with crushed tuff aggregate but decreases at higher concentrations of the compound ( 2 months; $10{ }^{\circ} \mathrm{C}$; mixed Na and Mg sulfate solution). Carmona-Quiroga et al. [8] showed that $15 \mathrm{wt} \% \mathrm{BaCO}_{3}$ addition to a $\mathrm{C}_{3} \mathrm{~A}$-high cement (11 wt $\%$ ) failed to protect pastes against a

\footnotetext{
* Corresponding author.

E-mail address: paulacq@ietcc.csic.es (P.M. Carmona-Quiroga).
} 
Table 1

Portland cement and $\mathrm{BaCO}_{3}$ addition chemical and mineralogical composition, BET specific surface and particle size.

\begin{tabular}{|c|c|c|c|c|}
\hline \multicolumn{5}{|c|}{ Chemical composition (wt\%) } \\
\hline Oxide & $\begin{array}{l}\text { CEM I } 42.5 \mathrm{R} \\
\text { (A) }\end{array}$ & $\begin{array}{l}\text { CEM I } 52.5 \text { N-SR } \\
5 \text { (B) }\end{array}$ & $\begin{array}{l}\text { Coarse } \mathrm{BaCO}_{3} \\
\text { (C) }\end{array}$ & $\begin{array}{l}\text { Fine } \mathrm{BaCO}_{3} \\
\text { (F) }\end{array}$ \\
\hline $\mathrm{CaO}$ & 62.98 & 61.75 & 0.10 & 0.09 \\
\hline $\mathrm{SiO}_{2}$ & 18.72 & 19.60 & 0.19 & 0.08 \\
\hline $\mathrm{Al}_{2} \mathrm{O}_{3}$ & 5.63 & 3.75 & 0.31 & \\
\hline $\mathrm{Fe}_{2} \mathrm{O}_{3}$ & 2.68 & 4.07 & & 0.04 \\
\hline $\mathrm{MgO}$ & 0.87 & 0.71 & & \\
\hline $\mathrm{SO}_{3}$ & 3.05 & 2.94 & 0.17 & \\
\hline $\mathrm{Na}_{2} \mathrm{O}$ & 0.04 & 0.03 & 0.76 & 0.67 \\
\hline $\mathrm{K}_{2} \mathrm{O}$ & 0.85 & 0.67 & 0.01 & \\
\hline $\mathrm{TiO}_{2}$ & 0.23 & 0.18 & 0.09 & 0.10 \\
\hline $\mathrm{SrO}$ & 0.05 & 0.05 & 0.30 & 0.07 \\
\hline $\mathrm{Mn}_{2} \mathrm{O}_{3}$ & 0.05 & 0.15 & & \\
\hline $\mathrm{ZnO}$ & 0.03 & 0.02 & & \\
\hline $\mathrm{P}_{2} \mathrm{O}_{5}$ & 0.05 & 0.06 & & \\
\hline $\mathrm{Cl}^{-}$ & 0.02 & 0.02 & & \\
\hline $\mathrm{Cr}_{2} \mathrm{O}_{3}$ & 0.00 & & & \\
\hline $\mathrm{Ba}^{\#} / \mathrm{BaO}^{\wedge}$ & $0.01^{\#}$ & & $75.95^{\wedge}$ & $77.45^{\#}$ \\
\hline L.o.I. & 2.3 & 3.2 & $22.1^{*}$ & $21.5^{*}$ \\
\hline Free lime & 0.19 & 0.15 & & \\
\hline \multicolumn{5}{|c|}{ Mineralogical phase composition (Rietveld) wt\% } \\
\hline $\mathrm{C}_{3} \mathrm{~S}$ & 65.15 & 66.94 & & \\
\hline $\mathrm{C}_{2} \mathrm{~S}$ & 11.41 & 13.62 & & \\
\hline $\mathrm{C}_{4} \mathrm{AF}$ & 6.87 & 12.11 & & \\
\hline $\mathrm{C}_{3} \mathrm{~A}$ & 10.71 & 0.87 & & \\
\hline Bassanite & 1.13 & 0.84 & & \\
\hline Gypsum & 1.58 & 1.60 & & \\
\hline Calcite & 3.14 & 4.03 & & \\
\hline WRp & 4.63 & 4.4 & & \\
\hline $\begin{array}{l}\text { BET }\left(\mathrm{m}^{2} /\right. \\
\mathrm{g})\end{array}$ & 1.45 & 1.48 & 0.57 & 2.81 \\
\hline$D_{50}$ & 13.07 & 8.68 & 11.45 & 2.37 \\
\hline
\end{tabular}

L.o.I $=$ loss on ignition at $1000{ }^{\circ} \mathrm{C} *$ at $1200{ }^{\circ} \mathrm{C}$.

$4.4(\mathrm{w} / \mathrm{v}) \% \mathrm{Na}_{2} \mathrm{SO}_{4}$ solution at room temperature (test duration $=1$ year). The non-uniform distribution of $\mathrm{BaCO}_{3}$ particles, as well as to the higher $\mathrm{C}_{3} \mathrm{~A}$ content in the former case, were considered responsible of that ineffective performance [8].

In that vein, whilst highly variable performance reported in the literature for nanoparticles $\left(\mathrm{SiO}_{2}, \mathrm{TiO}_{2}, \mathrm{Al}_{2} \mathrm{O}_{3}\right.$, etc.) $[16,17]$ in cementitious systems has been related to agglomeration and reactivity, these issues have not been extensively addressed. Microsize particles tend to cluster and form particle agglomerates similar to those observed in $\mathrm{BaCO}_{3}$, but of smaller size than nanosized particles [18]. The methods most widely used to confront this problem include mechanical shaking, sonication and the use of dispersants [19,20]. Blanco-Varela et al. [21] showed that dispersants addition to innovative sulfate-resistant (SR) cements may be counterproductive; certain lignosulfonate-containing formulations prompt thaumasite precipitation. Electrodeposition, an electrochemical method routinely used to coat metals by precipitation on an electrically charged surface [22], has been applied in concrete primarily to prevent or mitigate corrosion by closing cracks or blocking pores (with e.g. $\mathrm{ZnO}, \mathrm{ZnSO}_{4}$, $\mathrm{SiO}_{2}$, etc.) [23-25]. More recently, it has been used to disperse $\mathrm{SiO}_{2}$ nano and microparticles across the surface of portland cement particles prior to mixing with water and aggregates [26-28]. The electrodeposition of different micro-nanoparticles having different surface energy of hydroxyl groups is afforded by a soft-mechanical mixing in a humidity free environment. A net charge compensation of the dissimilar particles provides the anchoring mechanism of the nanoparticles onto the microparticles [29]. This unconventional dispersion procedure raises particle reactivity, yielding denser, more refined microstructures that lengthen cementitious material durability with a cost not higher than 5 USD/MT.

The present study deployed electrodeposition to enhance $\mathrm{BaCO}_{3}$ reactivity in pursuit of new, more sulfate-resistant cements. The aim was to assess the effect of two synthetic mineral admixtures of different particle size on $\mathrm{OPC}-\mathrm{BaCO}_{3}$ blend reactivity and durability.

\section{Materials and methods}

The materials used in this study included: two $99 \%$ pure synthetic $\mathrm{BaCO}_{3}$ powders with different particle sizes, coarser $\mathrm{BaCO}_{3}$ (named as C-BaCO ${ }_{3}$ ) supplied by T3Química (Barcelona, Spain) and finer $\mathrm{BaCO}_{3}$ (named as $\mathrm{F}-\mathrm{BaCO}_{3}$ ) by Acros Organics - Fisher Scientific (Madrid, Spain); and two portland cements, CEM I 42.5 R (cement A) and CEM I 52.5 N SR (cement B), supplied by Portland Valderrivas, Madrid The latter served as a reference in the study of resistance to external sulfate attack.

The starting materials were characterised chemically on a Bruker S8 TIGER XRF spectrometer and mineralogically on a Bruker D8 Advance (1.5406 $\AA$ CuK $\alpha 1$ and $1.5444 \AA$ CuK $\alpha 2$ radiation) X-ray diffractometer operating at $40 \mathrm{kV}$ and $30 \mathrm{~mA}$. Their particle size distributions were determined with a Malvern Mastersizer laser analyser (632.8 $\mathrm{nm} \mathrm{He-Ne}$ laser, cement particles suspended in ethanol and $\mathrm{BaCO}_{3}$ in water) and their BET specific surface on a Micromeretics ASAP $2010\left(\mathrm{~N}_{2}, 77 \mathrm{~K}\right)$ facility Finer and coarser $\mathrm{BaCO}_{3}$ particles were also examined under a Hitachi S-4800 SEM (scanning electron microscope).

The two synthetic $\mathrm{BaCO}_{3}$ materials were added to portland cement $\mathrm{A}$ at $15 \mathrm{wt} \%$ and $25 \mathrm{wt} \%$ using two methods: standard blending prior to mixing with water and electrodeposition, following a low-energy dry dispersion method (low shear rate) patented for dispersion of nanomaterials [27]. In this electrodeposition method, the cement samples with different $\mathrm{BaCO}_{3}$ additions were dried in an oven overnight at $120{ }^{\circ} \mathrm{C}$ and then mixed in a Turbula-type shaker with $15 \mathrm{~mm}$ diameter alumina balls [28]. Pastes of $\mathrm{BaCO}_{3}$-cement blends were named after the amount (15 or $25 \mathrm{wt} \%$ ) and type of added $\mathrm{BaCO}_{3}$ (C or F). Furthermore,
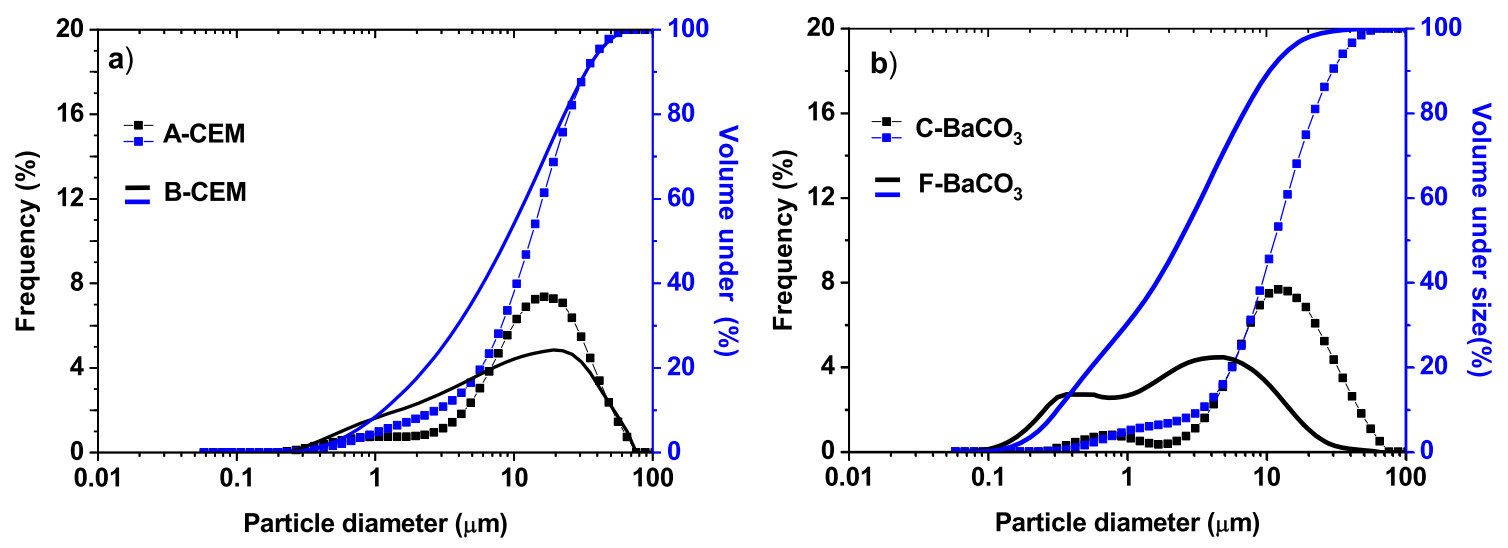

Fig. 1. Particle size distribution curves for raw materials: (a) cements and (b) $\mathrm{BaCO}_{3}$ particles. 

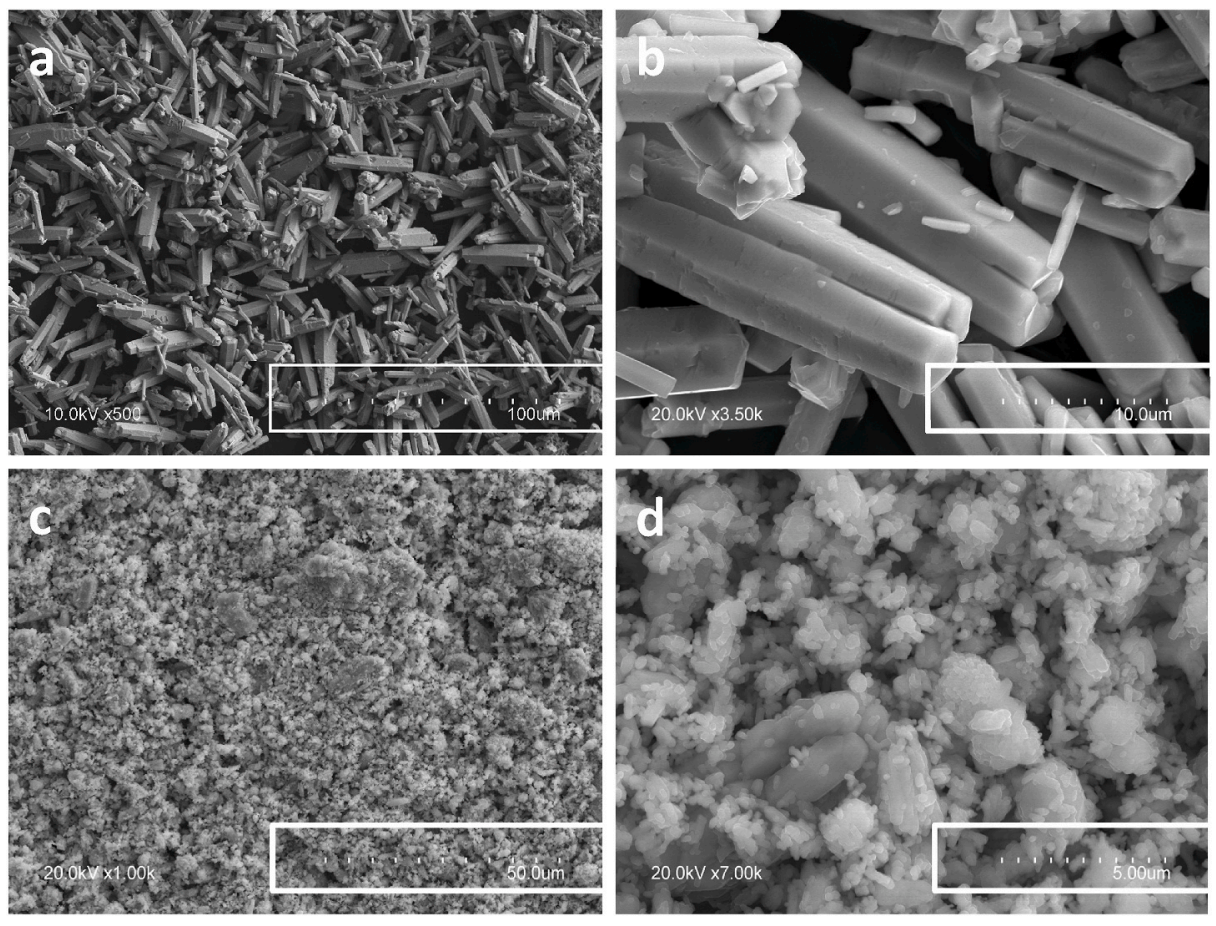

Fig. 2. SEM micrographs of $\mathrm{BaCO}_{3}$ particles: (a,b) coarse, $\mathrm{C}$, and (c,d) fine, $\mathrm{F}$.

Table 2

Minislump spread diameter for pastes $(\mathrm{w} / \mathrm{s}=0.35)$.

\begin{tabular}{|c|c|c|c|c|c|c|c|c|c|}
\hline & A & $15 \mathrm{C}$ & 15C-E & $25 \mathrm{C}$ & 25C-E & $15 \mathrm{~F}$ & $15 \mathrm{~F}-\mathrm{E}$ & $25 \mathrm{~F}$ & 25F-E \\
\hline$\varnothing(\mathrm{mm})$ & $91 \pm 2$ & $91 \pm 1$ & $95 \pm 1$ & $95 \pm 1$ & $98 \pm 1$ & $85 \pm 1$ & $83 \pm 1$ & $86 \pm 3$ & $83 \pm 1$ \\
\hline
\end{tabular}

Table 3

Heat flow and heat of hydration data from Fig. 3.

\begin{tabular}{llll}
\hline & $\mathrm{q}_{\max }(\mathrm{J} / \mathrm{gh})$ & $\mathrm{t}_{\max }$ (hours) & Q140h (J/g) \\
\hline A & 21.0 & 6.1 & 354.9 \\
$15 \mathrm{C}$ & 17.3 & 10.3 & 405.7 \\
$15 \mathrm{C}-\mathrm{E}$ & 17.0 & 11.1 & 409.5 \\
$25 \mathrm{C}$ & 17.2 & 11.5 & 437.0 \\
$25 \mathrm{C}-\mathrm{E}$ & 16.8 & 11.5 & 429.5 \\
$15 \mathrm{~F}$ & 19.0 & 11.5 & 414.6 \\
$15 \mathrm{~F}-\mathrm{E}$ & 20.5 & 11.4 & 390.0 \\
$25 \mathrm{~F}$ & 22.3 & 9.7 & 451.9 \\
$25 \mathrm{~F}-\mathrm{E}$ & 24.2 & 10.0 & 421.4 \\
\hline
\end{tabular}

pastes in which the mineral additions were electrodeposited were denoted by an additional E letter (15C-E, 25C-E, 15F-E and 25F-E).

Minislump tests were conducted to establish cement paste fluidity, all with a water/solid ratio $=0.35$. The non-standardised Kantro minislump test [30] is a simple method for assessing water demand from the cement paste slump diameter found on a spread table [31,32]. The same mixes were moulded into $60 \times 10 \times 10 \mathrm{~mm}^{3}$ specimens for the compressive strength determination and sulfate resistance test. Heat of hydration was determined on a Thermometric TAM isothermal conduction calorimeter at $25{ }^{\circ} \mathrm{C}$, applying in this case a water/solid ratio of 0.40 to homogenise the smaller samples required for calorimetric testing.

The effect of the mineral additions on the hydration of 2, 7 and 28 day pastes under water at $23^{\circ} \mathrm{C}$ (room temperature) was examined with the aforementioned X-ray diffractometer as well as with thermogravimetry (TG) and differential scanning calorimetry (DSC) simultaneous analyses on TA SDT Q60 instrument (in $\mathrm{N}_{2}$ up to $1200^{\circ} \mathrm{C}$, ramping at $10{ }^{\circ} \mathrm{C} / \mathrm{min}$ ). Compressive strength was tested on an Ibertest Autotest $200 / 10$ hydraulic test frame, whilst mercury intrusion porosity measurements were recorded with a Micromeritics Autopore IV 9500 V1.05 instrument. Dispersion of the two mineral additions in the dry cement and in the hydrated pastes was examined under the aforementioned SEM fitted with a Bruker energy-dispersive X-ray spectrometer. Hydration reactions were detained with isopropanol.

$\mathrm{BaCO}_{3}$-bearing and commercial SR cement (B) resistance to external sulfate attack was studied by soaking the specimens in a $50 \mathrm{~g} / \mathrm{L}$ solution of $\mathrm{Na}_{2} \mathrm{SO}_{4}$ (standard exposure solution [33]) for 6 months at $23{ }^{\circ} \mathrm{C}$ (volume proportion of solution to paste specimens $=5.5$; modified from Ref. [33]). Analogous specimens were soaked in water under the same conditions. Mechanical strength (speed $(0.07 \mathrm{kN} / \mathrm{s})$ and section modified from Ref. [34]) was recorded after initial $2 \mathrm{~d}$ water curing and after $28 \mathrm{~d}, 91 \mathrm{~d}$ and $180 \mathrm{~d}$ and paste mineralogy was found for the water and sulfate-soaked specimens with XRD at $180 \mathrm{~d}$.

\section{Results and discussion}

\subsection{Characterization of the starting materials}

Chemical and mineralogical composition of both selected cements $(\mathrm{A}, \mathrm{B})$ and both $\mathrm{BaCO}_{3}$ admixtures $(\mathrm{C}, \mathrm{F})$ and their particle size and surface area are shown in Table 1 . Of the two cements, the sulfateresistant one (B) (with limited $C_{3} A$ content) is finer $\left(D_{50}=8.68\right.$ vs. 13.07, Table 1) because of its higher grade (52.5). Both cements presented a unimodal distribution as seen in Fig. 1, unlike the finer of all four starting materials, the finer $\mathrm{BaCO}_{3}\left(\mathrm{~F}, \mathrm{D}_{50}=2.37\right.$ and BET surface area $=2.81 \mathrm{~m}^{2} / \mathrm{g}$; Table 1) that showed a bimodal distribution (Fig. 1).

When examined under SEM, the finer $\mathrm{BaCO}_{3}$ particles (F) (Fig. 2) are either elongated with rounded faces and length $<5 \mu \mathrm{m}$ or rounded whit 

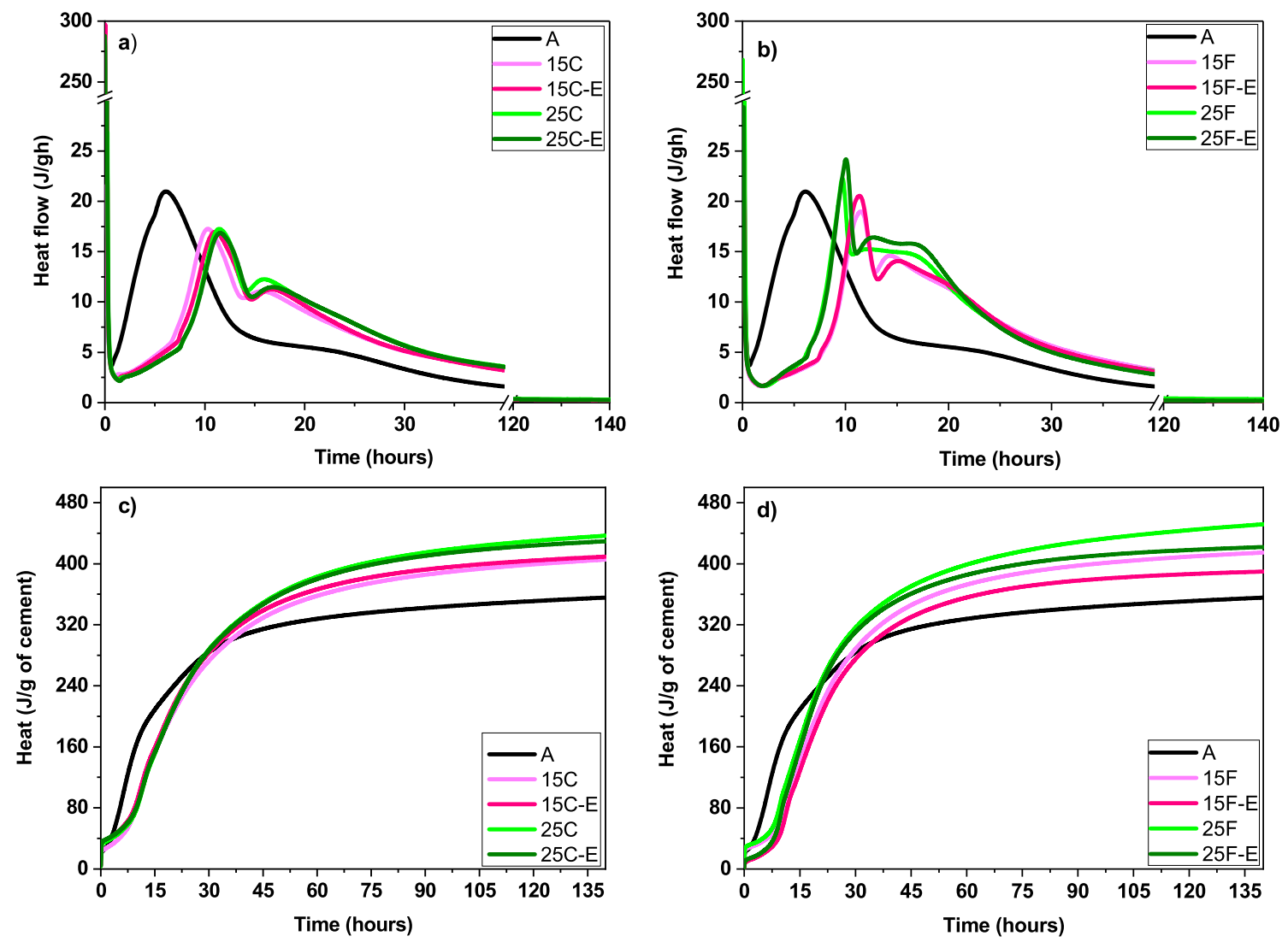

Fig. 3. Heat flow (a,b) and heat of hydration (c,d) normalised to cement content for the different cement pastes.

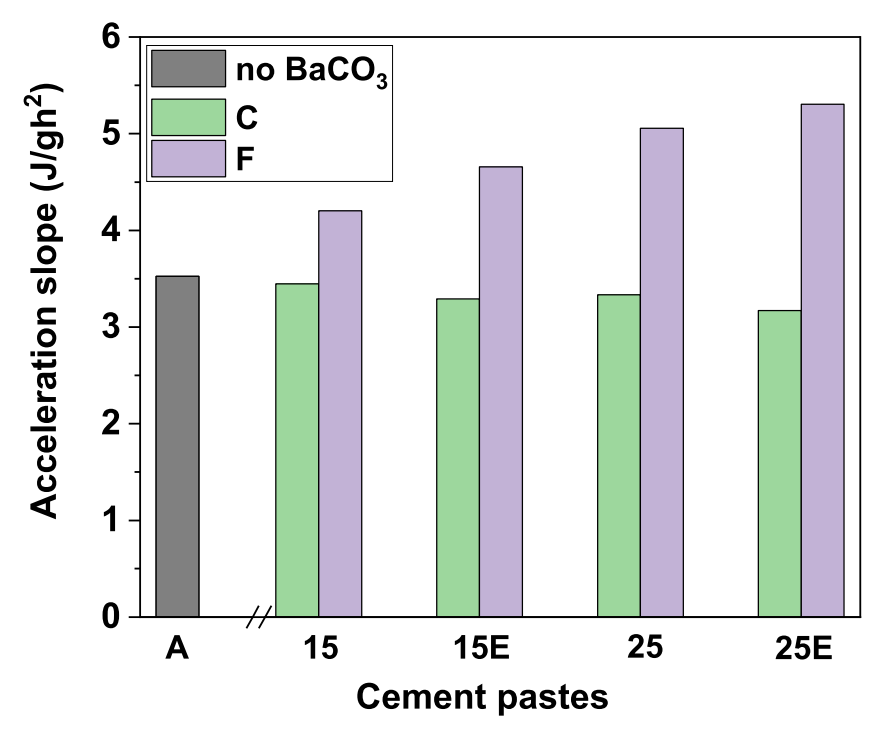

Fig. 4. Acceleration slope on the calorimetric curves for the different cement pastes.

sizes down $500 \mathrm{~nm}$ powder. On the contrary, the coarser (C) barium carbonate particles were elongated with faceted faces indicating well crystallization and with lengths $>10 \mu \mathrm{m}$ and thickness $<4 \mu \mathrm{m}$ (Fig. 2).

\subsection{Minislump}

$\mathrm{BaCO}_{3}$-bearing cement paste fluidity was studied (Table 2) to analyse its workability in comparison with neat cement.

The results showed that of all the mixes, only $15 \mathrm{C}$ kept the same paste fluidity than that of neat OPC. In contrast, 25C increases the fluidity, while finer $\mathrm{BaCO}_{3}$ addition decreases it. The fluidity variation is greater at higher replacement ratio and at electrodeposition.

The relationship between paste specific surface and decline in spread diameter is clearly visible at both replacement ratios. Specific surface is not the sole factor governing paste fluidity, which also depends on particle morphology, quantity, packing density and wettability. Consequently, the opposite may be observed, with finer particles contributing to raise paste fluidity at low replacement ratios ( $<5 \mathrm{wt} \%$ silica fume) [35], by filling the voids that generate inter-particle friction.

\subsection{Early paste hydration at 2, 7 and $28 d$}

\subsubsection{Calorimetry}

Calorimetry was deployed to determine the effect of the two types of $\mathrm{BaCO}_{3}$ on the portland cement hydration rate. Unlike finely ground limestone [36-39], the presence of this mineral addition lengthens the induction period [40,41], retarding the appearance of the main exothermal signal by $3.6 \mathrm{~h}-5.4 \mathrm{~h}$ and therefore $\mathrm{C}-\mathrm{S}-\mathrm{H}$ nucleation (Table 3; Fig. 3). Reasons for reaching later the supersaturation level for the nucleation of C-S-H [42] in the systems bearing Ba could be related with the water content [43] (same $\mathrm{w} / \mathrm{s}=0.4$ for all blends) and associated dilution effect on calcium and silicate concentration.

Nonetheless, acceleration begins, with a steeper slope in the mixes containing $\mathrm{F}-\mathrm{BaCO}_{3}$ (finer than the reference cement particles) due to the filler effect, stimulating nucleation and reversing initially retarded C-S-H growth (Fig. 4).

The shape of the heat flow curves also changes for barium carbonate with higher specific surface values. Compositions $25 \mathrm{~F}$ and 25F-E exhibiting narrower and more intense peaks than portland cement (Fig. 3). Moon et al. [39] observed a similar effect on the peaks shape with smaller particle size of barium carbonate. The next exothermal signal, attributed to the redissolution of aluminates reacting with $\mathrm{CaCO}_{3}$ 

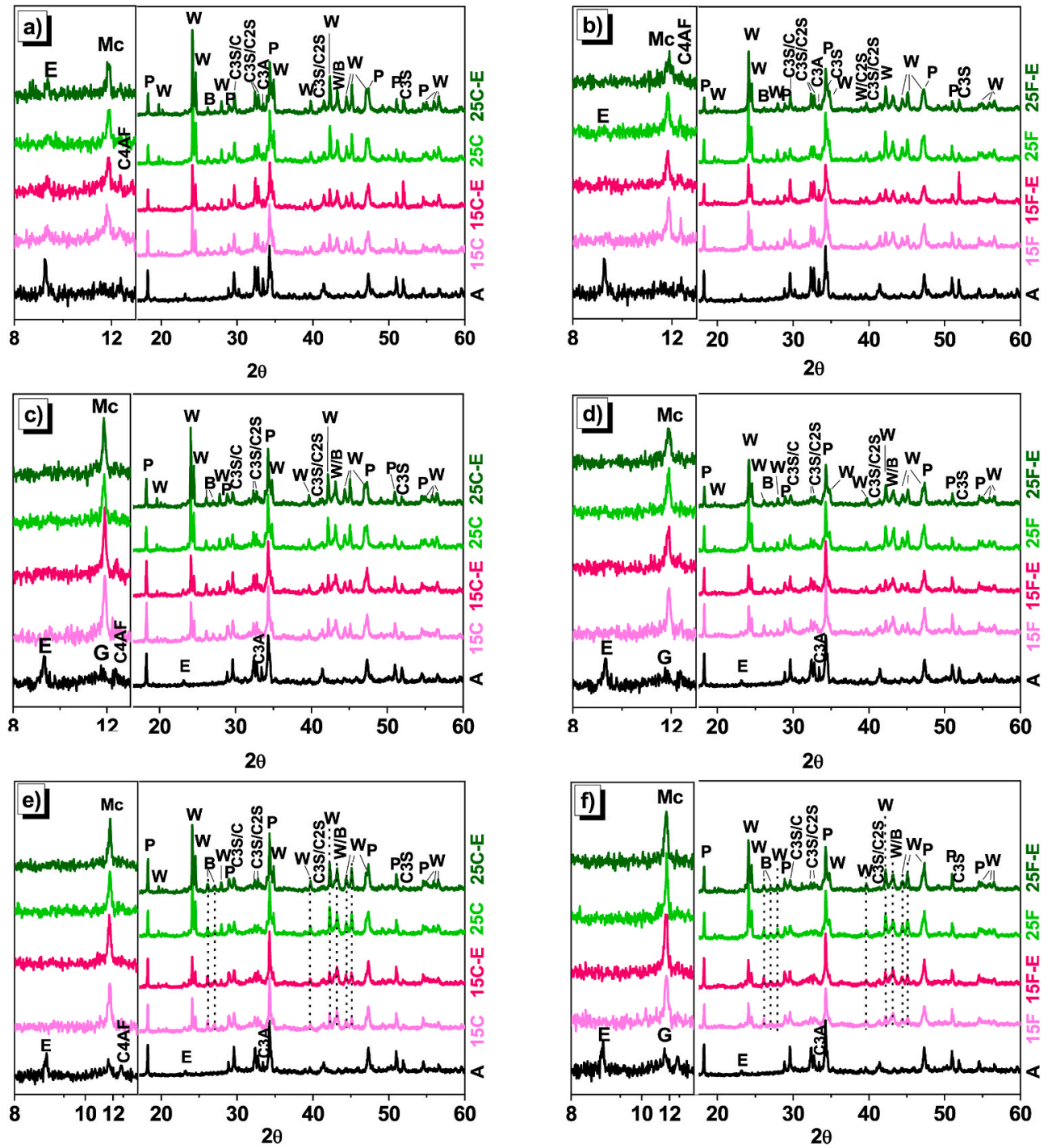

Fig. 5. Two day (a,b), $7 \mathrm{~d}(\mathrm{c}, \mathrm{d})$ and $28 \mathrm{~d}(\mathrm{e}, \mathrm{f})$ diffractograms for the different cement pastes. $\mathrm{E}=$ ettringite; $\mathrm{Mc}=$ calcium monocarboaluminate hydrate; $\mathrm{G}=$ gypsum; $\mathrm{P}=$ portlandite; $\mathrm{W}=\mathrm{BaCO}_{3} ; \mathrm{B}=$ barite, clinker phases $=\mathrm{C} 3 \mathrm{~S}, \mathrm{C} 2 \mathrm{~S}, \mathrm{C} 3 \mathrm{~A}, \mathrm{C} 4 \mathrm{AF}$.

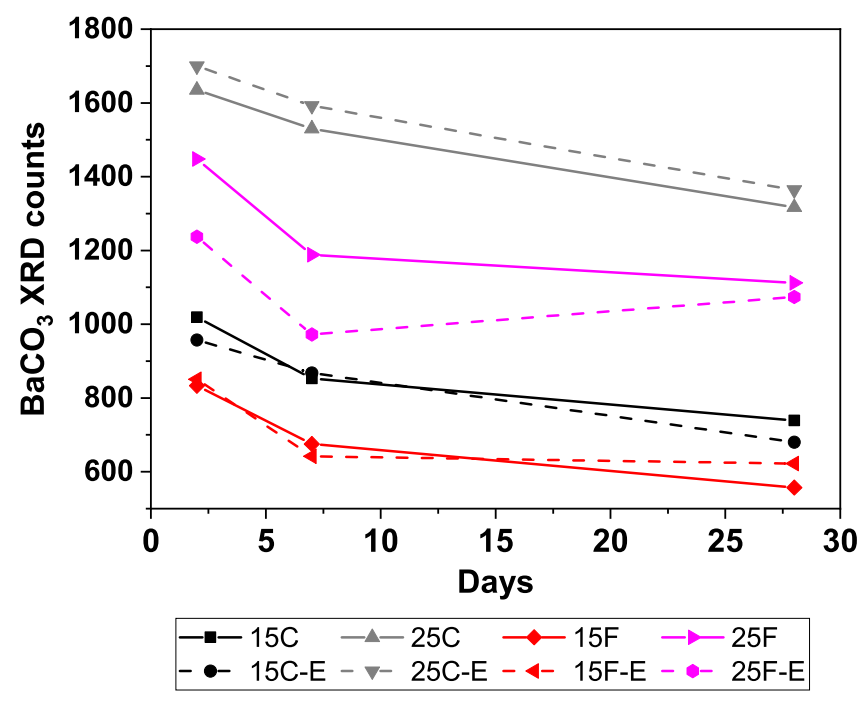

Fig. 6. XRD peak intensity of $\mathrm{BaCO}_{3}$ over hydration time.
Table 4

Non-normalised decarbonation and total weight loss for the hydrated cement pastes.

\begin{tabular}{|c|c|c|c|c|c|c|}
\hline \multirow[t]{2}{*}{${ }^{\circ} \mathrm{C}$} & 2 days & \multirow[t]{2}{*}{ total } & 7 days & \multirow[t]{2}{*}{ total } & 28 days & \multirow[t]{2}{*}{ total } \\
\hline & $473-1200$ & & $473-1200$ & & $473-1200$ & \\
\hline A & 5.40 & 18.98 & 5.22 & 19.82 & 5.85 & 22.00 \\
\hline $15 \mathrm{C}$ & 7.59 & 19.27 & 8.44 & 21.66 & 7.58 & 22.66 \\
\hline 15C-E & 7.25 & 18.95 & 8.01 & 21.38 & 7.37 & 22.32 \\
\hline $25 \mathrm{C}$ & 8.80 & 19.13 & 9.23 & 21.67 & 9.22 & 23.04 \\
\hline 25C-E & 8.68 & 18.74 & 9.20 & 21.52 & 8.87 & 22.84 \\
\hline $15 \mathrm{~F}$ & 8.07 & 19.69 & 7.68 & 22.19 & 8.21 & 23.64 \\
\hline 15F-E & 7.43 & 18.50 & 8.04 & 22.91 & 8.34 & 23.98 \\
\hline $25 \mathrm{~F}$ & 8.95 & 20.09 & 8.61 & 22.23 & 9.62 & 24.35 \\
\hline 25F-E & 7.97 & 18.59 & 8.75 & 22.94 & 9.58 & 24.43 \\
\hline
\end{tabular}

to form calcium monocarboaluminate, appears much earlier on the curves for the aforementioned two pastes than for OPC. Ettringite transformation is brought forward in all the $\mathrm{BaCO}_{3}$ samples, but more perceptibly in $25 \mathrm{~F}$ and $25 \mathrm{~F}-\mathrm{E}$.

The deposition method affects the hydration rate for $\mathrm{F}-\mathrm{BaCO}_{3}$, where the acceleration slope (first $6 \mathrm{~h}-10 \mathrm{~h}$ ) is slightly steeper (Figs. 3 and 4). After the first $20 \mathrm{~h}-36 \mathrm{~h}$, all the $\mathrm{BaCO}_{3}$-bearing cements release more 
Table 5

Bound water and portlandite content normalised to cement content.

\begin{tabular}{|c|c|c|c|c|c|}
\hline & $\begin{array}{l}\text { Age } \\
\text { (d) }\end{array}$ & $\begin{array}{l}\text { Bound } \\
\text { water }\end{array}$ & $\begin{array}{l}\mathrm{CH} \\
\text { (normalised) }\end{array}$ & $\begin{array}{l}\text { Bound } \\
\text { water }\end{array}$ & $\begin{array}{l}\mathrm{CH} \\
\text { (normalised) }\end{array}$ \\
\hline \multirow[t]{3}{*}{ A } & 2 & 12.1 & 15.4 & & \\
\hline & 7 & 13.1 & 16.7 & & \\
\hline & 28 & 15.1 & 17.5 & & \\
\hline \multicolumn{2}{|c|}{$\begin{array}{l}\text { Deposition } \\
\text { method }\end{array}$} & \multicolumn{2}{|c|}{ Standard } & \multicolumn{2}{|c|}{ Electrodeposition } \\
\hline \multirow[t]{3}{*}{$15 \mathrm{C}$} & 2 & 11.9 & 15.6 & 12.0 & 15.5 \\
\hline & 7 & 13.6 & 18.3 & 14.1 & 18.2 \\
\hline & 28 & 15.8 & 21.4 & 15.6 & 21.5 \\
\hline \multirow[t]{3}{*}{$25 \mathrm{C}$} & 2 & 11.6 & 15.7 & 11.3 & 15.5 \\
\hline & 7 & 14.6 & 19.2 & 14.1 & 19.5 \\
\hline & 28 & 16.1 & 22.1 & 16.2 & 23.0 \\
\hline \multirow[t]{3}{*}{$15 \mathrm{~F}$} & 2 & 11.6 & 16.0 & 11.3 & 14.5 \\
\hline & 7 & 15.1 & 20.5 & 16.0 & 20.1 \\
\hline & 28 & 16.3 & 22.1 & 16.7 & 22.0 \\
\hline \multirow[t]{3}{*}{$25 \mathrm{~F}$} & 2 & 12.7 & 16.8 & 12.3 & 15.3 \\
\hline & 7 & 16.1 & 21.3 & 17.1 & 21.6 \\
\hline & 28 & 17.6 & 23.5 & 17.7 & 23.5 \\
\hline
\end{tabular}

Table 6

$28 \mathrm{~d}$ strength activity index (SAI).

\begin{tabular}{lllllllll}
\hline & $15 \mathrm{C}$ & $15 \mathrm{C}-\mathrm{E}$ & $25 \mathrm{C}$ & $25 \mathrm{C}-\mathrm{E}$ & $15 \mathrm{~F}$ & $15 \mathrm{~F}-\mathrm{E}$ & $25 \mathrm{~F}$ & $25 \mathrm{~F}-\mathrm{E}$ \\
\hline SAI & 82 & 92 & 85 & 81 & 77 & 87 & 76 & 74 \\
\hline
\end{tabular}

heat (normalised to cement content) than the neat OPC (Fig. 3), as a result of the filler effect that has been described to cause a rise in interparticle shear rate [44]. Heat of hydration rises with $\mathrm{BaCO}_{3}$ content. With coarser $\mathrm{C}-\mathrm{BaCO}_{3}$ no differences as a function of the deposition method are observed in reaction rate or total heat of hydration at the end of the test $(140 \mathrm{~h})$, whereas with the finer $\mathrm{F}-\mathrm{BaCO}_{3}$, electrodeposition helps to release greater heat than standard blending [36,39].

\subsubsection{Mineralogy and $\mathrm{BaCO}_{3}$ distribution}

The diffractograms for the hydrated samples show that, despite barite precipitation (Equation (1) [10]), only primary ettringite is stable in the presence of $\mathrm{BaCO}_{3}$ at the earliest age $(2 \mathrm{~d})$, alongside calcium monocarboaluminate hydrate. Aluminates also reacted with carbonates to yield this latter hydrate (low intensity of its strongest line at $2 \theta=$ $11.7^{\circ}$ ) (Fig. 5). Utton et al. [40] also observed the presence of ettringite in $24 \mathrm{~h}$ samples, although their materials had a higher $\mathrm{BaCO}_{3}$ content (30 $\mathrm{wt} \%$ replacement ratio) and they worked at a slightly lower temperature $\left(20^{\circ} \mathrm{C}\right)$.

$$
\begin{aligned}
& \mathrm{BaCO}_{3}+\mathrm{Ca}_{2} \mathrm{SO}_{4} \cdot 2 \mathrm{H}_{2} \mathrm{O}+2 \mathrm{OH}^{-} \rightarrow \mathrm{BaSO}_{4}+\mathrm{CaCO}_{3} \\
& +\mathrm{Ca}(\mathrm{OH})_{2}+2 \mathrm{H}_{2} \mathrm{O}
\end{aligned}
$$

In this study, the $2 \mathrm{~d}$ pastes with $\mathrm{F}-\mathrm{BaCO}_{3}$ exhibit weaker ettringite signals than in the analogous mixes with $\mathrm{C}-\mathrm{BaCO}_{3}$ (Fig. 6). Ettringite is absent altogether only for 25F-E, which contained the higher percentage of finer barium carbonate particles with dispersion attained by electrodeposition. According to a thermodynamic stability study of hydrated cement phases in the presence of barium (simplified closed $\mathrm{CaO}-\mathrm{BaO}-\mathrm{Al}_{2} \mathrm{O}_{3}-\mathrm{CaSO}_{4}-\mathrm{CaCO}_{3}-\mathrm{H}_{2} \mathrm{O}$ system at $25{ }^{\circ} \mathrm{C}$ [45]), ettringite and gypsum can only precipitate in the presence of very low barium concentrations (in this system in particular, at $\left[\mathrm{Ba}^{2+}\right] \leq 0.1176 \mathrm{mmol} / \mathrm{kg}$ and $\leq 1.510^{-4} \mathrm{mmol} / \mathrm{kg}$, respectively).

By day 7, however, ettringite decomposes for all materials (Utton et al. [40] reported a weaker signal at that age) and more calcium monocarboaluminate precipitates at its expense (as revealed by the increase in intensity of its main peak, Fig. 5), whilst the hydration reactions continue to progress more rapidly in mix 25F-E (attested to by the decline in the intensity of the $\mathrm{C}_{3} \mathrm{~S}$ signal at around $52{ }^{\circ} 2 \theta$ ) as $\mathrm{BaCO}_{3}$ dissolves (Fig. 6). This fact is in contrast with the calorimetric findings where more (normalised) heat is released by the equivalent standard $\operatorname{mix} 25 \mathrm{~F}$.

After $28 \mathrm{~d}$, the deposition method has no effect on finer $\mathrm{BaCO}_{3}$ reactivity. Substantial amounts of unreacted $\mathrm{BaCO}_{3}$ remain for the 28 d ages samples (Fig. 6), although, high density of barium compounds that absorb standard X-ray sources hinders the assessment of its reaction degree.

This finding also observed by Utton et al. [40] in OPC pastes with 30 $\mathrm{wt} \% \mathrm{BaCO}_{3}$, might initially be thought to be available to immobilise external sulfate ions [10] (see section 3.4).

Portlandite, calcite and unreacted clinker phases are present at all three ages, as expected (Fig. 5).

The derivative of TG curves for the 2, 7 and $28 \mathrm{~d}$ pastes showed in Fig. 7 reveals three main weight losses ranges. The first, between approximately $90{ }^{\circ} \mathrm{C}-300{ }^{\circ} \mathrm{C}$, is attributable primarily to $\mathrm{C}-\mathrm{S}-\mathrm{H}$ and calcium monocarboaluminate dehydration in the $\mathrm{OPC}-\mathrm{BaCO}_{3}$ mixes and for neat OPC samples to ettringite and $\mathrm{C}-\mathrm{S}-\mathrm{H}$ dehydration. Portlandite dehydroxylation takes place at around $440{ }^{\circ} \mathrm{C}$ and $\mathrm{CO}_{2}$ loss from the various carbonates present $\left(\mathrm{CaCO}_{3}\right.$ in calcium monocarboaluminate hydrate, calcite and $\mathrm{BaCO}_{3}$ ) from $600{ }^{\circ} \mathrm{C}$ onward. $\mathrm{BaCO}_{3}$ decomposes at higher temperatures and generates four endothermal signals at $818{ }^{\circ} \mathrm{C}$ (polymorphic transformation from rhomboid to the hexagonal system), $977^{\circ} \mathrm{C}$ (from the hexagonal to the cubic system), $1030{ }^{\circ} \mathrm{C}$ and the most intense at $1113^{\circ} \mathrm{C}$. Whilst decomposition starts with the second peak, the maximum DTG signal is at $1098{ }^{\circ} \mathrm{C}$ [7]. For calcium monocarboaluminate, the decarboxylation signal is around $865^{\circ} \mathrm{C}$ [46] and for calcite around $700{ }^{\circ} \mathrm{C}$. Decarbonation signal position depends not only on the number of phases present, but also on their fineness [47], which would induce the appearance of several peaks in this temperature range.

Decarbonation weight loss (Table 4) rise not only with the replacement ratio (as more carbonates are included in the systems) but with $\mathrm{BaCO}_{3}$ particle size as the finest addition $(\mathrm{F})$, in contrast with the samples bearing the coarser $\mathrm{BaCO}_{3}$, exhibit higher interaction Given the thermal stability of barite, its presence is not quantifiable [46]. (In some DSC curves (Figure not shown) a very weak endothermic peak at around $1158{ }^{\circ} \mathrm{C}$ attributed to the polymorphic transformation from rhombohedral to monoclinic system can be detected) [48].

Since weight loss in the various carbonates overlapped between 473 and $1200{ }^{\circ} \mathrm{C}$ [8] (Table 4), calculations are performed to quantify the values for portlandite dehydration (normalised to cement content) and bound water loss (modifying the equation in Ref. [49] to measure bound water in a single stage up to $385^{\circ} \mathrm{C}$ ) (Table 5). Hydrate weight loss rises perceptibly with curing time and more intensely in the materials containing $\mathrm{BaCO}_{3}$. More portlandite precipitates out of the finer, more reactive addition and at the higher replacement ratio $(6 \%$ more in $25 \mathrm{~F}$ than in A and $2 \%$ more than in $15 \mathrm{C}$ after $28 \mathrm{~d}$ ). As ettringite contained a much higher proportion of crystallization water than monocarboaluminate and since portland cement contained ettringite and the $\mathrm{BaCO}_{3}$-additioned cements primarily calcium monocarboaluminate hydrate, the bound water measurements show only slightly greater losses in the samples with $\mathrm{BaCO}_{3}$, despite their higher degree of reaction. More specifically, a difference of $2.5 \%$ is observed between $28 \mathrm{~d}$ A and $25 \mathrm{~F}$ bound water loss, with greater calcium monocarboaluminate dehydration (signal at $144{ }^{\circ} \mathrm{C}-148{ }^{\circ} \mathrm{C}$ ) in the latter (Fig. 7).

Small weight loss differences between electrodeposition and standard method were recorded in the $2 \mathrm{~d}$ and $7 \mathrm{~d}$ pastes with $\mathrm{F}-\mathrm{BaCO}_{3}$ (mean values of $\pm 0.5 \%$ and maximum differences of $0.9 \%$ in bound water and $1.5 \%$ in portlandite content in the $2 \mathrm{~d}$ and $7 \mathrm{~d}$ pastes with $\mathrm{F}-\mathrm{BaCO}_{3}$, Table 5).

$\mathrm{BaCO}_{3}$ distribution in the $28 \mathrm{~d}$ hydrated pastes was examined under a scanning electron microscope (Fig. 8). Large quantities of unreacted $\mathrm{BaCO}_{3}$ particles on which small $(<2 \mu \mathrm{m}) \mathrm{BaSO}_{4}$ crystals precipitated are observed in the $\mathrm{BaCO}_{3}$-bearing cement pastes (Fig. 9a). The larger sized particles, C, with a characteristic prismatic shape were dispersed uniformly across the matrix (Fig. 9b), unlike the finer particles, which tend 

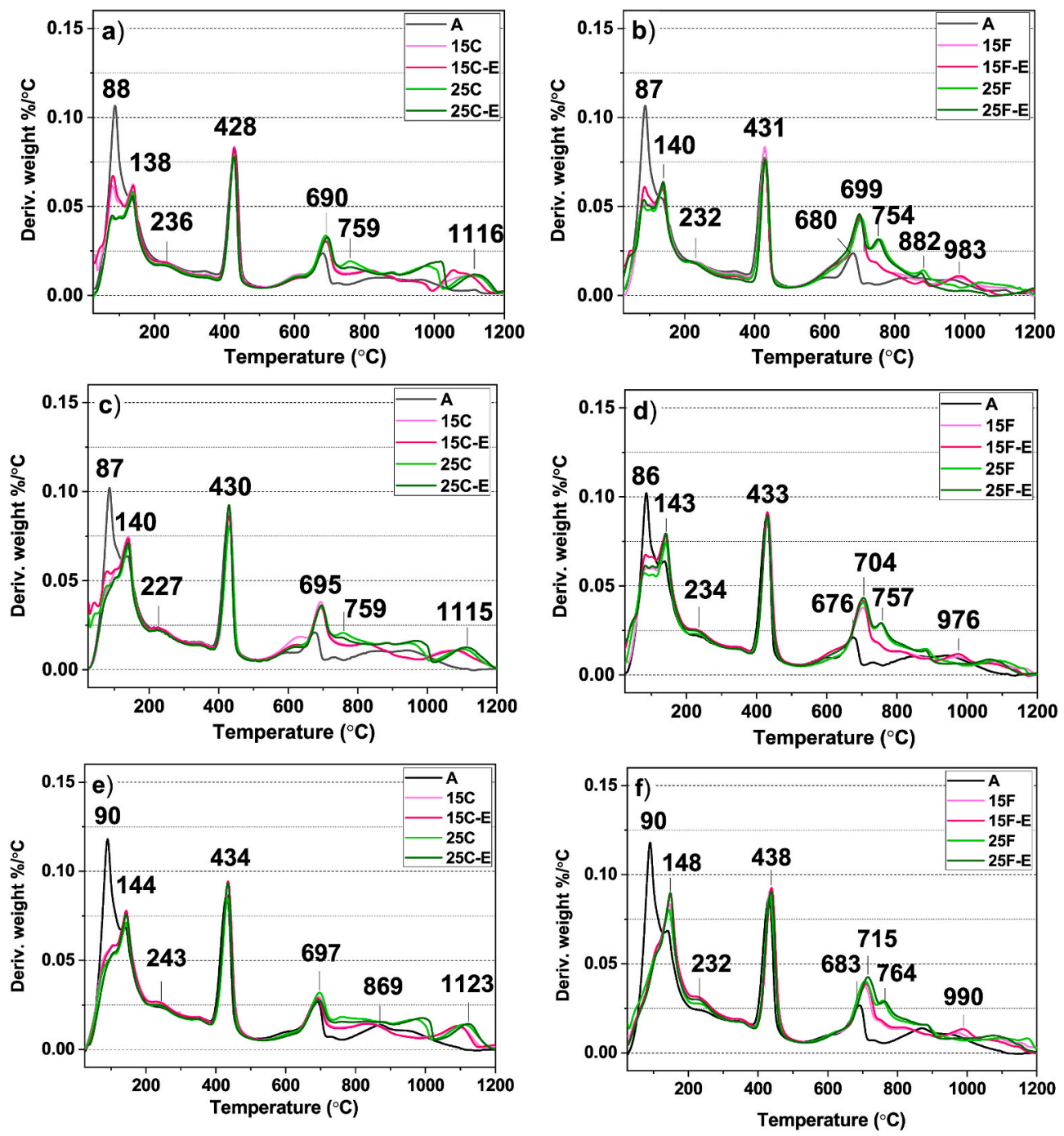

Fig. 7. Derivative TG curves for 2,7 and $28 \mathrm{~d}$ cement pastes with a) coarse (C) or (b) fine (F) $\mathrm{BaCO}_{3}$.

to form $50 \mu \mathrm{m}-200 \mu \mathrm{m}$ clusters, even when electrodeposited (Fig. 9c). Similar results were reported by Xiong et al. [10] and Carmona-Quiroga and Blanco-Varela [7] who used mechanical methods to blend cement with this very dense $\left(4.43 \mathrm{~g} / \mathrm{cm}^{3}\right.$ [13] $)$ micrometric addition, the former authors at $30 \mathrm{wt} \%$ and $10 \mathrm{wt} \%$ and the latter at $15 \mathrm{wt} \%$ replacement. Electrodeposition is used here in an attempt to reduce or minimise such clustering. Fine $\mathrm{BaCO}_{3}$ particles are initially dispersed in anhydrous cement very effectively with that method, as the micrographs in Fig. 9d show. However $\mathrm{BaCO}_{3}$ fine particles in contact with the mixing water tend to cluster, and both the clustered and non-clustered particles can be found throughout the paste (Fig. 9c) [18].

\subsubsection{Microstructure and mechanical properties}

Both types of $\mathrm{BaCO}_{3}$ modify paste pore structure in the first $48 \mathrm{~h}$, with higher total porosity and volume of pores under $10 \mathrm{~nm}$ in OPC$\mathrm{BaCO}_{3}$ than in OPC. The volume of capillary pores $(0.1 \mu \mathrm{m}-0.01 \mu \mathrm{m})$ declines more steeply with curing time in the pastes with the finer carbonate, as a result of denser particle packing [50] (Fig. 10). So at $28 \mathrm{~d}$, all blended pastes have lower total porosity than the reference cement with $\mathrm{F}-\mathrm{BaCO}_{3}$ specimens exhibiting the lowest values (dropped by $35-58 \%$ from 2 to $28 \mathrm{~d}$ ). The deposition procedure did not appear to be a determining factor for porosity at any age (Fig. 11).

Xiong et al. [10] also observed $14 \mathrm{~d}$ pastes with smaller ( $5 \mathrm{wt} \%$ to 10 $\mathrm{wt} \%$ ) amounts of $\mathrm{BaCO}_{3}$ to exhibit lower total porosity and a smaller critical pore diameter than the reference cement paste. They attributed such effect to accelerated $\mathrm{C}_{3} \mathrm{~A}$ hydration driven by gypsum consumption by $\mathrm{BaCO}_{3}[10,51]$. Su et al. [9] identified barite precipitation as the factor inducing the decline in porosity in mortars prepared with limestone-bearing cements and just $0.5 \mathrm{wt} \%$ to $1.5 \mathrm{wt} \% \mathrm{BaCO}_{3}$ or $\mathrm{Ba}$ $(\mathrm{OH})_{2}$. In contrast, mortars with $10 \mathrm{wt} \%$ to $15 \mathrm{wt} \% \mathrm{BaCO}_{3}$ and no internal sulfates were more porous than the reference materials with no $\mathrm{BaCO}_{3}$ and $5 \%$ gypsum [7]. In this case, the higher the percentage of $\mathrm{BaCO}_{3}$ added the greater the specimen porosity was.

Small amounts of limestone also reduce OPC paste total porosity by raising the volume of hydration products, furthermore this addition stabilizes a voluminous phase such as ettringite and therefore prevents its conversion to calcium monosulfoaluminate, which occupies less volume [52]. On the contrary, it has been reported that larger amounts of $\mathrm{CaCO}_{3}$ (such as $25 \mathrm{wt} \%$ [53]) raise portland cement paste porosity; however, the use of low water/powder ratios $(\leq 0.35)$ with the help of superplasticizers can cause a decrease in total porosity in blends with such high limestone contents ( $\leq 50 \mathrm{wt} \%)$ [54].

$\mathrm{BaCO}_{3}$ bearing cement pastes exhibit lower absolute compressive strength than the A-cement paste at all three ages due to their lower cement content (dilution effect) (Fig. 11). Nonetheless, except in two of the samples with lower amounts of $\mathrm{BaCO}_{3}(15 \mathrm{C}$ and $15 \mathrm{~F})$ the relative strength referred to a given cement content (strength activity index, SAI, Equation (2)) is greater than or equal to the values recorded for the reference cement (reactive effect) (Table 6).

$\mathrm{SAI}=$ blended cement paste compressive strength unblended OPC 

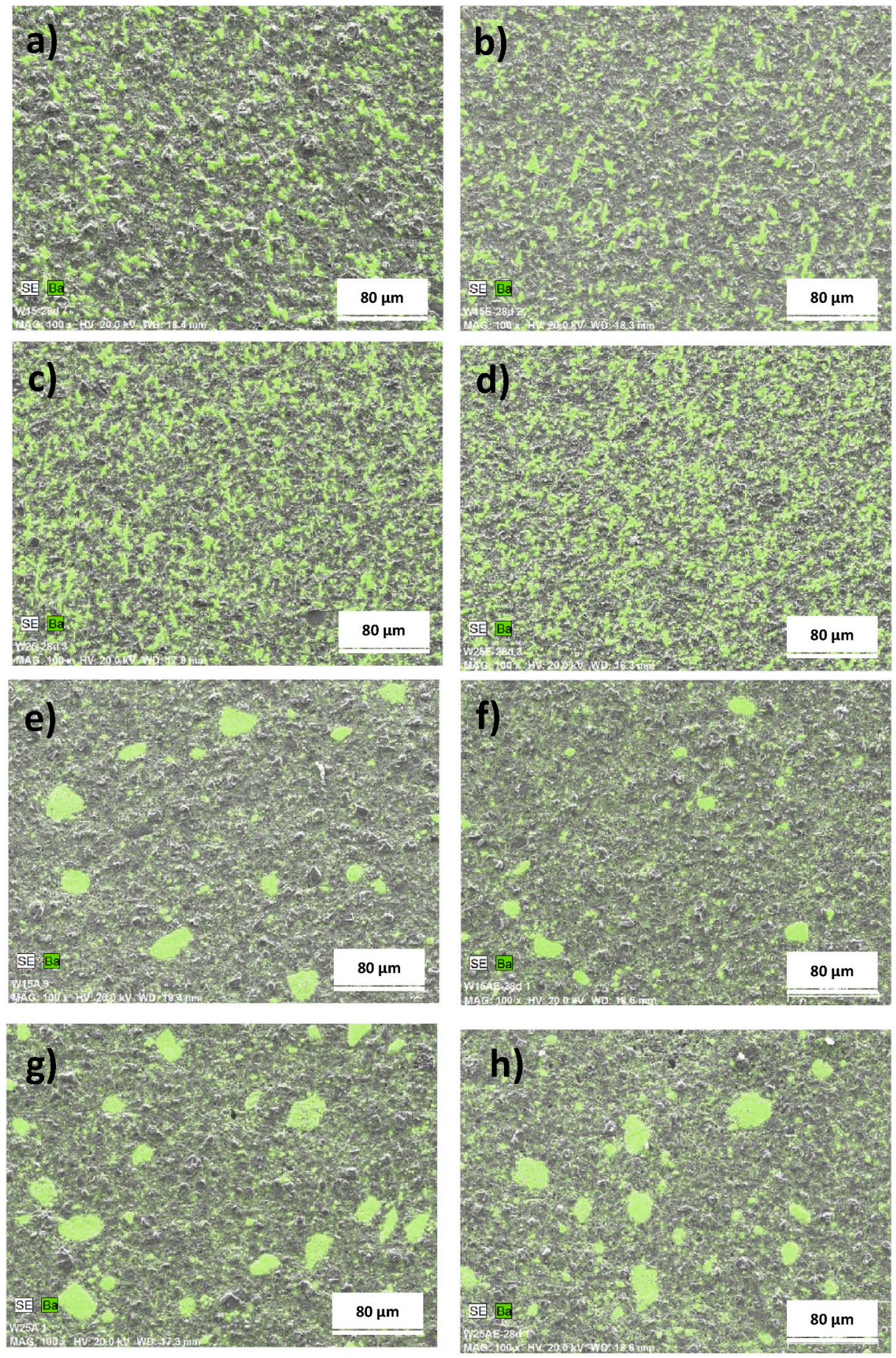

Fig. 8. SEM micrograph mapping for 28 d pastes: a)15C; b) 15C-E; c) 25C; d) 25C-E; e) 15F; f) 15F-E; g) 25F; h) 25F-E.

paste compressive strength $\mathrm{x} 100$ (2).

In all cases strength rises steadily with reaction time, with the 28 $\mathrm{d}$ mixes reaching $52 \mathrm{MPa}-65 \mathrm{MPa}$ and the portland reference $75 \mathrm{MPa}$. On the whole, allowing for testing error, the greater the replacement ratio, the lower is the compressive strength. Xiong et al. [10], however, using lower $\mathrm{BaCO}_{3}$ contents ( $5 \mathrm{wt} \%$ and $10 \mathrm{wt} \%$ ), observed higher strength in the $28 \mathrm{~d}$ and $60 \mathrm{~d}$ additioned pastes than in the reference, although the pattern reversed after $91 \mathrm{~d}$.

Here the $7 \mathrm{~d}$ and $28 \mathrm{~d}$ compressive strengths closest to the OPC values are found for the electrodeposited samples with the lower amount of $\mathrm{BaCO}_{3}$. The pastes with the finer addition (F) exhibited lower mechanical performance than those prepared with the coarser (C) barium carbonate, despite their smaller total and capillary porosities (Figs. 10 and 11). Considering this decrease in compressive strength with the electrodeposited finer addition, the possible use of even finer electrodeposited $\mathrm{BaCO}_{3}$ particles to increase their reactivity in the search for a more efficient substitution is not straightforward and should be further explored.

One explanation for that initially contradictory result is the fact that the greater proportion of insoluble barite that filled the pores would not contribute in any substantial manner to mechanical strength development. The use of barite as an aggregate to partially replace ordinary aggregate in dense concrete manufacture has in fact been shown to induce a decline in compressive strength [55]. Lower strength in the 

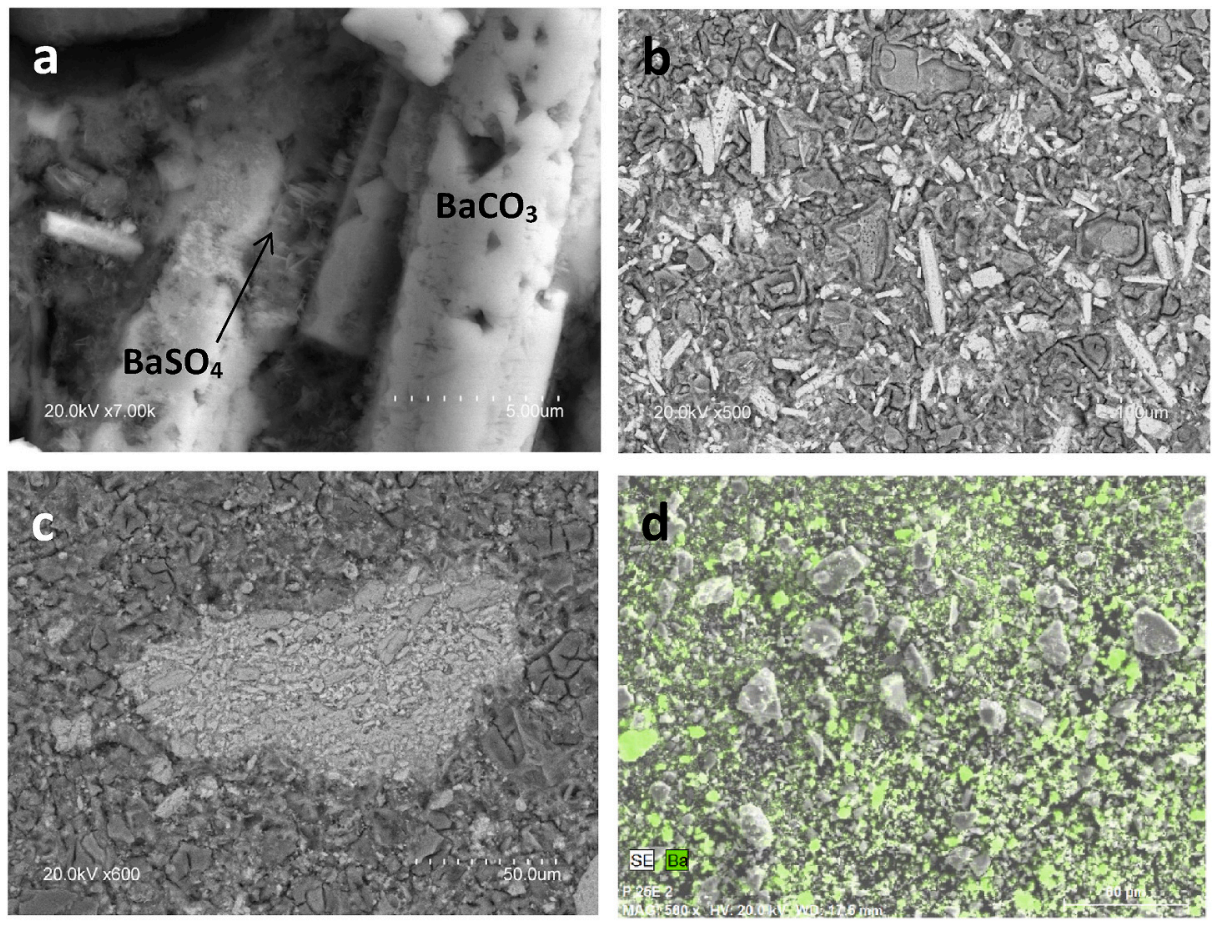

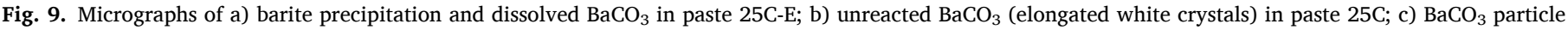
cluster in paste 15F-E; and d) fine $\mathrm{BaCO}_{3}$ electrodeposited on anhydrous cement.

$\mathrm{F}-\mathrm{BaCO}_{3}$ cement pastes may also be attributed to the higher water sorptivity of those mixes (Table 2), for the addition has a higher BET specific surface than OPC $\left(2.8 \mathrm{~m}^{2} / \mathrm{g}\right.$ vs $\left.1.5 \mathrm{~m}^{2} / \mathrm{g}\right)$. The presence of more entrained air pores in the $2 \mathrm{~d}$ and $28 \mathrm{~d}$ pastes would have been the result of less uniform mixing.

\subsection{Sulfate attack}

An initial visual inspection of the pastes prepared with neat cements, $\mathrm{A}$ and $\mathrm{B}$, and $\mathrm{BaCO}_{3}$-bearing cements that were soaked in a $5 \% \mathrm{Na}_{2} \mathrm{SO}_{4}$ solution for $180 \mathrm{~d}$ reveals that most of the specimens, including the ones made with sulfate-resistant cement $B$, showed signs of slight to moderate decay (Fig. 12). Two compositions, 15C-E and 15F-E are found to be in good condition. These cement pastes are the two that after initial curing have compressive strengths closest to the unblended cement values. The greatest decay due to loss of the external layer is observed in specimens $25 \mathrm{~F}$ (where scaling is more intense) and 25C, the two with the lowest strength values at the outset of the durability test. All the other specimens show cracks along the edges, shorter in pastes B, A and 25F-E and longer and with associated material loss in 15F, 25F-E and 25C-E.

Calcium monocarboaluminate hydrate precipitated in all pastes whether soaked in water or in a sulfate solution (). It has been found that its presence would increase the stability of the cementitious system to sulfate attack since it is more thermodynamic stable than monosulfate and other calcium-aluminate hydrates [56]. In any case, expansive products such as secondary ettringite and gypsum precipitate altogether in all the specimens, even those apparently unaltered, although the quantity of the latter mineral does not suffice to eclipse the presence of portlandite (Fig. 13). Conventionally, gypsum precipitates in the presence of highly concentrated sulfate solutions [57] as in this study. Barite that immobilises a fraction of external sulfates also form in the pastes with $\mathrm{BaCO}_{3}$.Due to its low solubility substantial amounts of unreacted $\mathrm{BaCO}_{3}$ are observed in all the $180 \mathrm{~d}$ specimens, but less in the sulfate solution than in water (Fig. 14). In other words, dissolved Ba can immobilise only a limited amount of external sulfates (Fig. 13), so gypsum and ettringite are able to precipitate. In fact, the periodical analysis of $\mathrm{Ba}^{2+}$ concentration in sulfate test solutions in which mortars elaborated with $\mathrm{BaCO}_{3}$-bearing cements were immmersed for 6 months revealed that this cation is readily immobilised [58]. Analysed concentrations were below the detection limit $(<0.006 \mathrm{ppm})$ of an ICP-EOS instrument in the majority of the cases which limits its toxicity effects.

$\mathrm{Su}$ et al. [9] reported that $0.5 \mathrm{wt} \%, 1 \mathrm{wt} \%$ and $1.5 \mathrm{wt} \% \mathrm{Ba}(\mathrm{OH})_{2}$ raised resistance to thaumasite $\left(\mathrm{CaSiO}_{3} \cdot \mathrm{CaSO}_{4} \cdot \mathrm{CaCO}_{3} \cdot 15 \mathrm{H}_{2} \mathrm{O}\right)$ formation in limestone-containing portland cement mortar more effectively than the same percentages of $\mathrm{BaCO}_{3}$ (even though ettringite and thaumasite precipitated). This fact was attributed to the higher solubility of the former that promotes pore structure refinement and sulfate immobilisation as barite. In contrast, an excess of barite formation seems to be counterproductive, as seen in this study and observed by Wen et al. [11] for mortars prepared with cements bearing over $4 \mathrm{wt} \% \mathrm{Ba}(\mathrm{OH})_{2}$, where the volume instability generated [11] induced a decline in specimen compressive strength.

Fig. 15 depicts mechanical strength development in the pastes soaked in a concentrated $(50 \mathrm{~g} / \mathrm{L})$ sodium sulfate solution. Compressive strength is observed to decline significantly with test time in paste W25F only, where greatest physical decay is observed (Fig. 12) (lower 180 $\mathrm{d}$ than initial strength). Unlike deposition method, replacement ratio appears to be a determining factor in $\mathrm{OPC}-\mathrm{BaCO}_{3}$ mix durability.

\section{Conclusions}

In the search for novel sulfate resistant cements (SR), this study explores the effect of different $\mathrm{BaCO}_{3}$ particles (two different fineness and morphology) replacing portland cement by $15 \mathrm{wt} \%$ and $25 \mathrm{wt} \%$ with different mixing procedures (standard and electrodeposition) on the reactivity and resistance of to a $5 \% \mathrm{Na}_{2} \mathrm{SO}_{4}$ solution sulfate attack of those cement blends. The conclusions are set out below.

- At both replacement ratios the two mineral additions studied $\left(\mathrm{BaCO}_{3}\right.$ $(\mathrm{C}), \mathrm{D}_{50}=11.45 \mu \mathrm{m}$ and $\mathrm{BaCO}_{3}(\mathrm{~F}), \mathrm{D}_{50}=2.37 \mu \mathrm{m}$ ) retard portland $42.5 \mathrm{R}$ cement initial hydration (first $20 \mathrm{~h}-36 \mathrm{~h}$ ). Nonetheless, after 

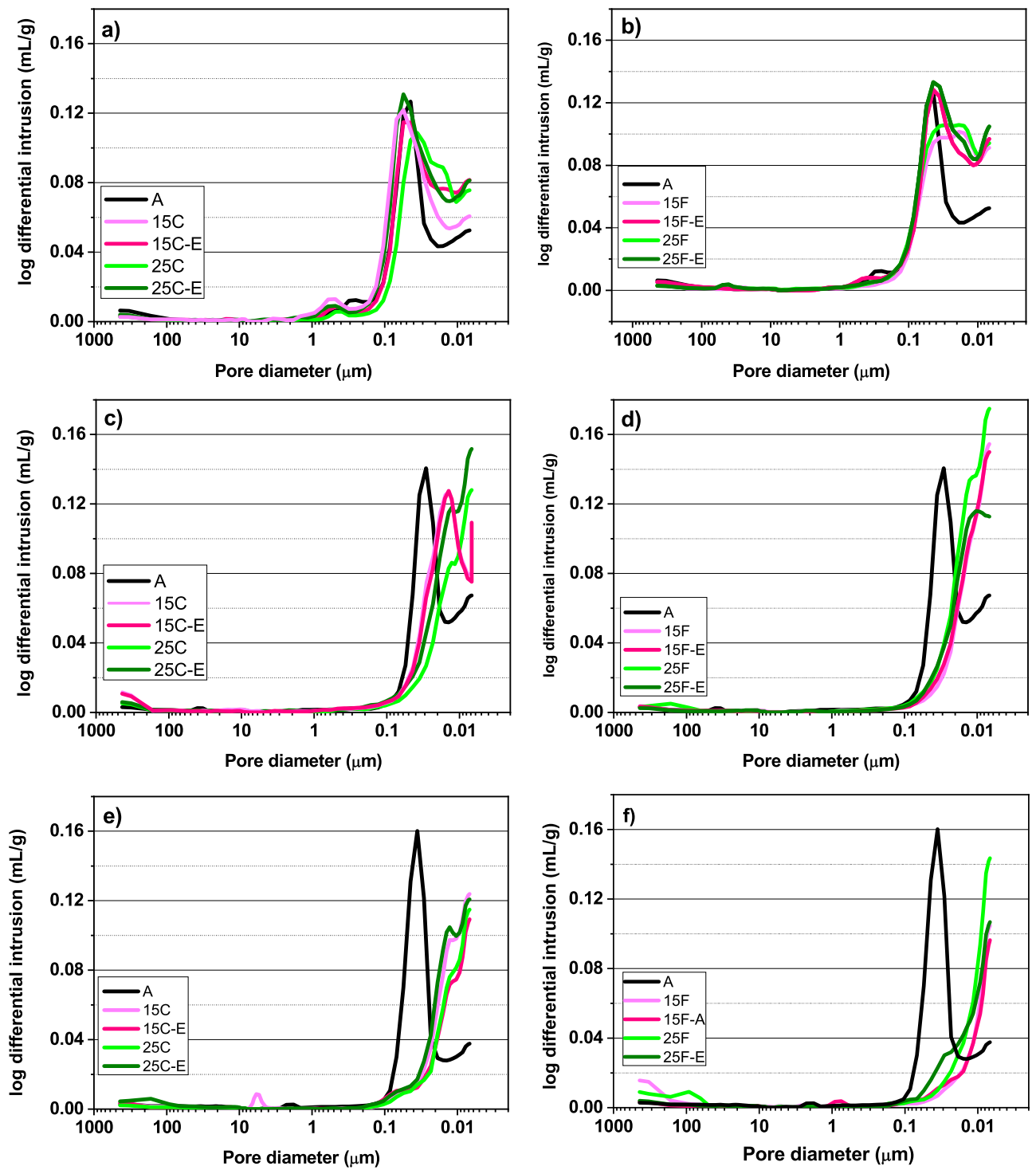

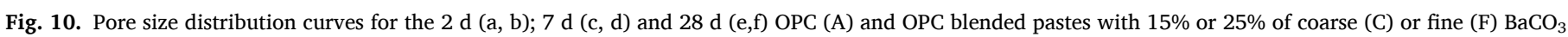
electrodeposited (E) or standard mixed. 

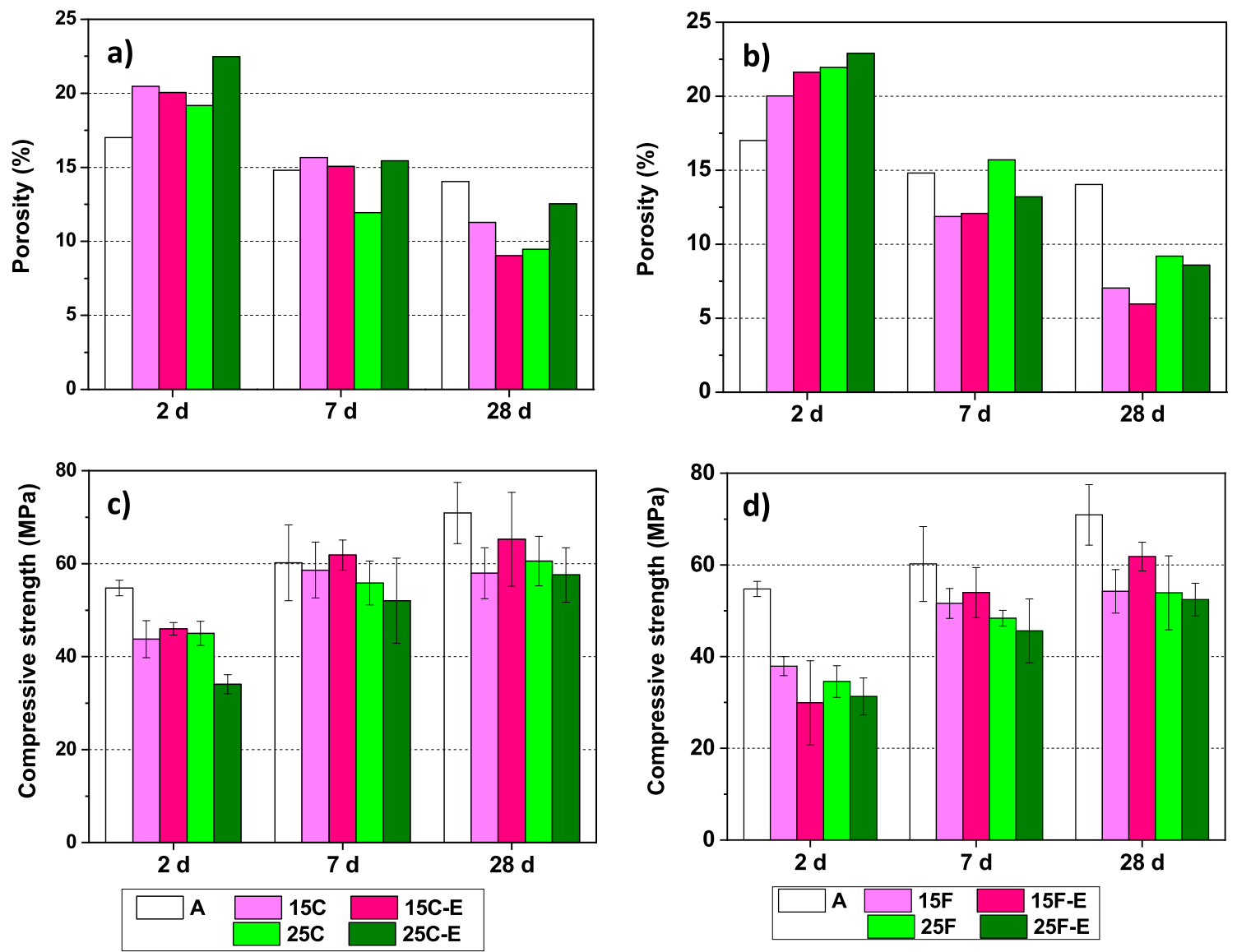

Fig. 11. Two day, $7 \mathrm{~d}$ and $28 \mathrm{~d}$ total porosity and compressive strength in cement pastes with coarse (a,c) or fine (b,d) $\mathrm{BaCO}_{3}$.

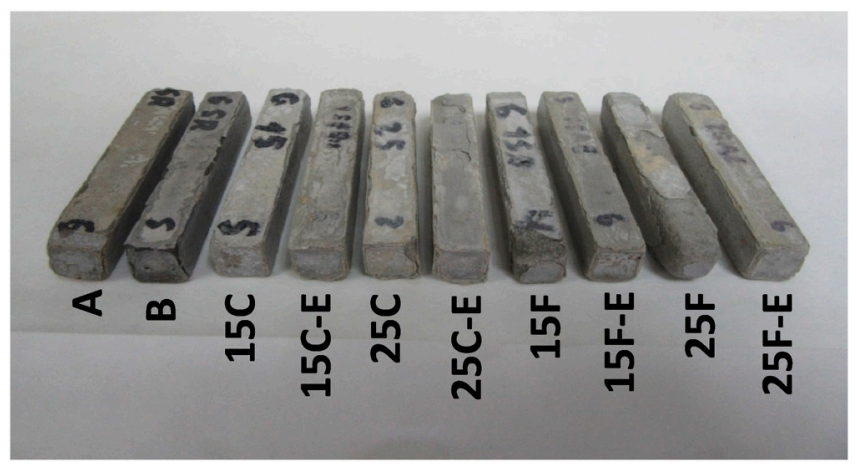

Fig. 12. Pastes of reference cements (A and $\mathrm{B}$ ) and $\mathrm{BaCO}_{3}-\mathrm{OPC}$ blended cements after soaking for $180 \mathrm{~d}$ in a $\mathrm{Na}_{2} \mathrm{SO}_{4}$ solution.

that initial period the heat of hydration in the $\mathrm{OPC}^{-\mathrm{BaCO}_{3}}$ mixes (normalised to cement content) rises with addition content.

- The deposition method affects reactivity of the finer particles only (F), which, even when electrochemically deposited, cluster at early ages upon contact with water. XRD analysis reveals such differences in the $2 \mathrm{~d}$ materials, when primary ettringite can still precipitate in the presence of the scant $\mathrm{BaCO}_{3}$ dissolved, and in the $7 \mathrm{~d}$ pastes. In the $28 \mathrm{~d}$ materials, in contrast, reactivity varies only with particle quantity and fineness.

- Adding more, finer and more reactive particles induces greater cement hydrates (such as calcium monocarboaluminate), (normalised) portlandite and $\mathrm{CaCO}_{3}$ and $\mathrm{BaSO}_{4}$ precipitation, the fourth as a result of the interaction between $\mathrm{BaCO}_{3}$ and internal sulfates. That in turn refines the pore structure, leading to a decline in $28 \mathrm{~d}$ neat OPC total porosity. Strength is lower, although significant ( $>50 \mathrm{MPa}$ at $28 \mathrm{~d}$ ), in the mixes than in the reference cement, given the lower cement content in the former.

- Despite their lower porosity, pastes prepared with fine particles are less sulfate-resistant than those bearing coarse particles. That is attributable to the higher amount of early age barite precipitation that does not contribute to mechanical strength, and therefore has a significant impact on the sulfate resistance test.

- The OPC mixes containing $15 \mathrm{wt} \% \mathrm{BaCO}_{3}$ exhibit the highest sulfate resistance when exposed to a $5 \% \mathrm{Na}_{2} \mathrm{SO}_{4}$ solution for $180 \mathrm{~d}$, even outperforming a commercial SR cement due to a balance between two factors: the high initial resistance of these mixes, very near that 

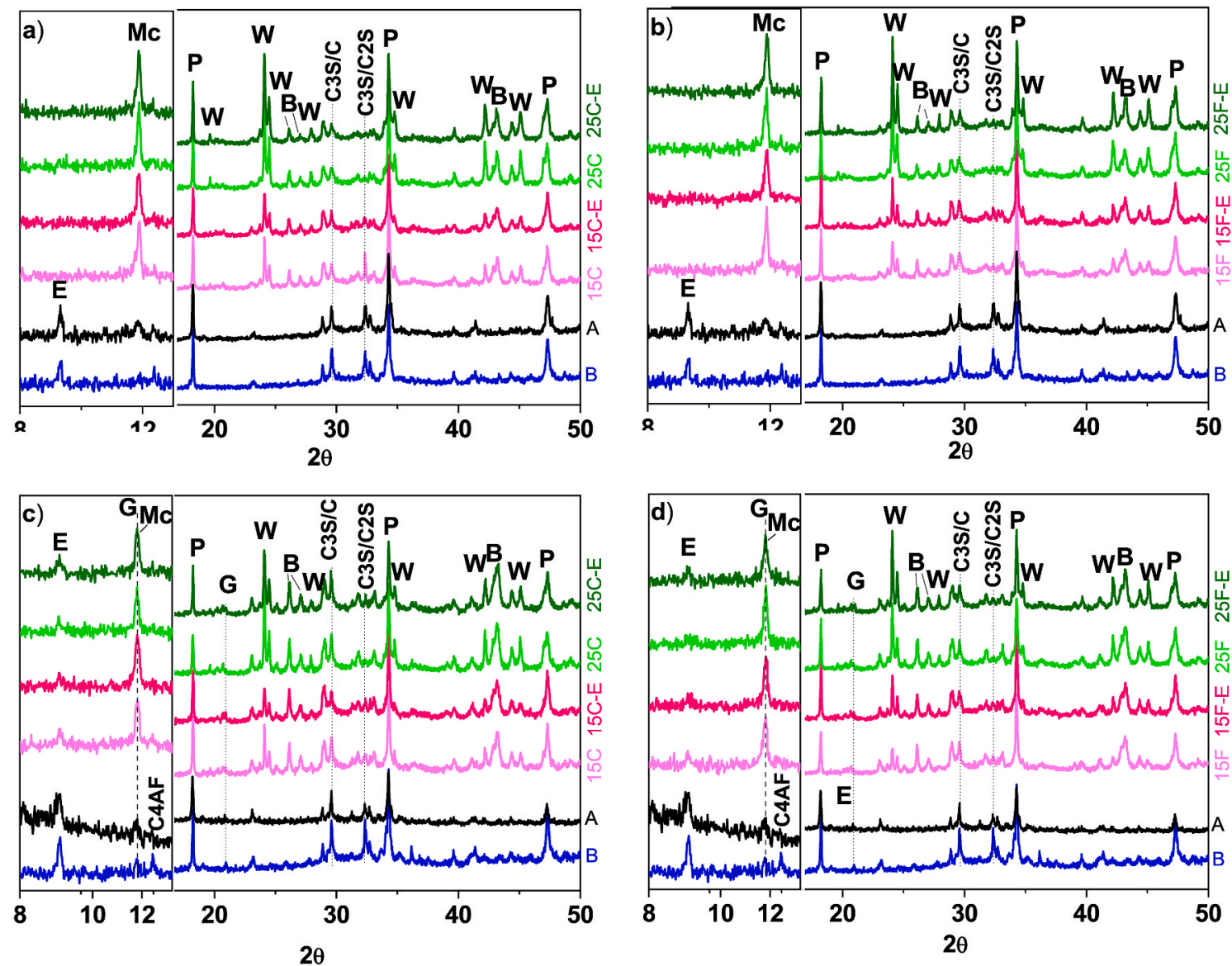

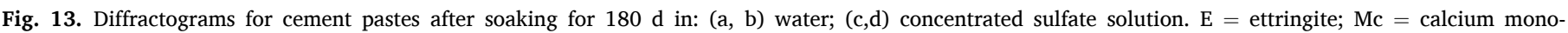
carboaluminate hydrate; $\mathrm{G}=$ gypsum; $\mathrm{P}=$ portlandite; $\mathrm{W}=\mathrm{BaCO}_{3} ; \mathrm{B}=$ barite, clinker phases $=\mathrm{C} 3 \mathrm{~S}, \mathrm{C} 2 \mathrm{~S}, \mathrm{C} 3 \mathrm{~A}, \mathrm{C} 4 \mathrm{AF}$.

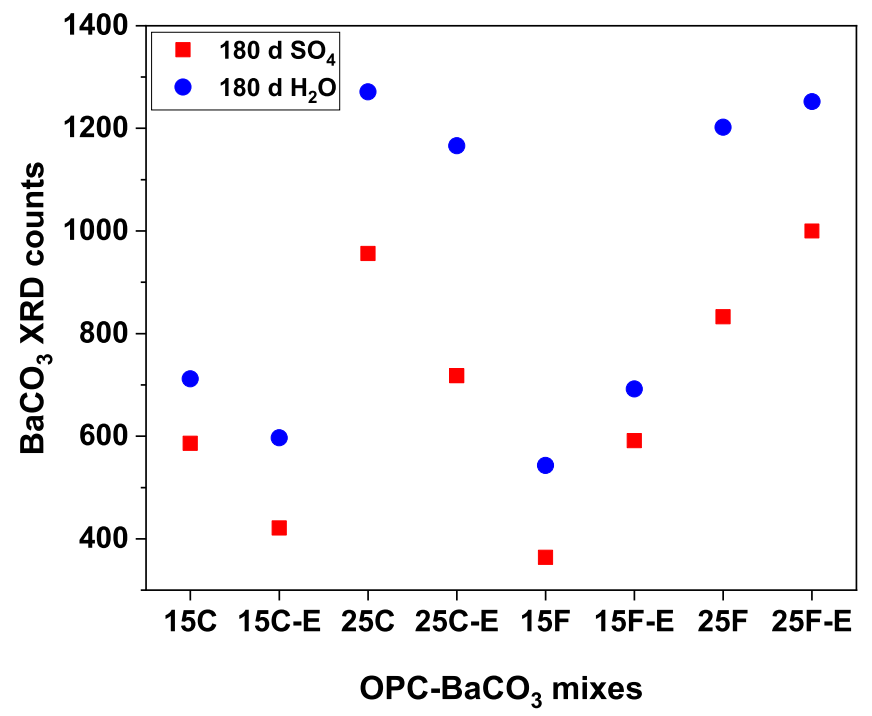

Fig. 14. XRD peak intensity of $\mathrm{BaCO}_{3}$ in the pastes soaked in the $5 \% \mathrm{Na}_{2} \mathrm{SO}_{4}$ solution or in water for 180 days. 

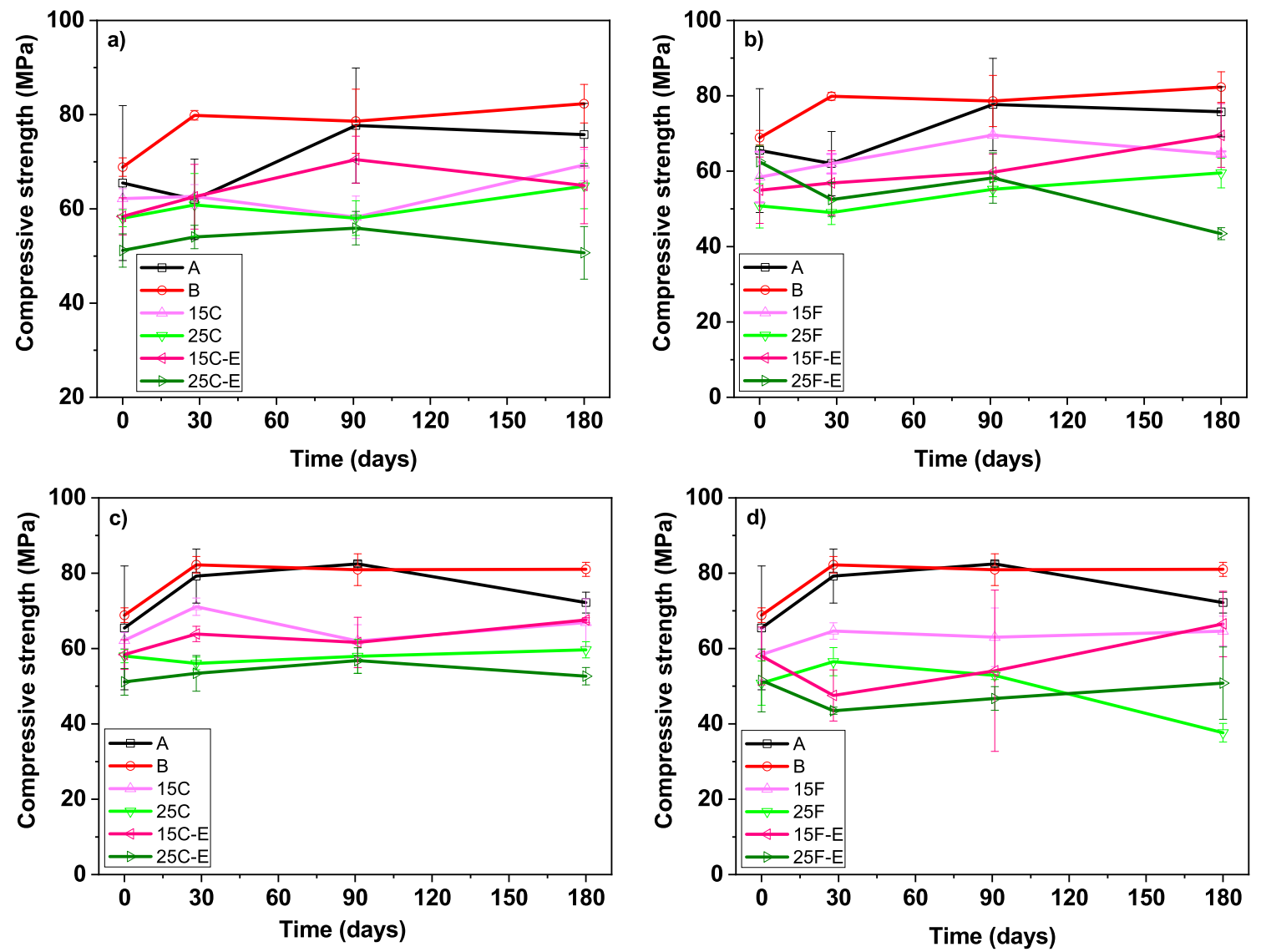

Fig. 15. Compressive strength in reference and blended cements (a,b) immersed in water and (c,d) immersed in sulfate solution.

of the unblended cement, and the partial immobilisation of sulfates as barite. On the contrary, the mixes with higher amounts of the addition, where barite forms and compressive strength is lower, decay most intensely (scaling).

- Given its low solubility, $\mathrm{BaCO}_{3}$ does not react fully after $180 \mathrm{~d}$. The resulting store of barium that might initially be deemed favourable as a long-term buffer against sulfate ingress proves to be counterproductive in systems exposed to high sulfate concentrations (laboratory tests), which induce excess barite precipitation.

\section{Declaration of competing interest}

The authors declare that they have no known competing financial interests or personal relationships that could have appeared to influence the work reported in this paper.

\section{Acknowledgements}

This study was funded by the Spanish Ministry of the Economy and Competitiveness and the European Regional Development Fund, BIA2015-73237-JIN project (MINECO/ERDF; EU) and MAT201786450-C4-1-R. The authors wish to thank Grupos Cementos Portland Valderrivas and in particular Germán García Pérez for the supply of the OPCs used.

\section{References}

[1] UNE-EN 197-1, Cement - Part 1: Composition, Specifications and Conformity Criteria for Common Cements, AENOR, Madrid, 2011.

[2] M. Whittaker, L. Black, Current knowledge of external sulfate attack, Adv. Cement Res. 27 (2015) 532-545, https://doi.org/10.1680/adcr.14.00089.
[3] F. Bellmann, J. Stark, Prevention of thaumasite formation in concrete exposed to sulphate attack, Cement Concr. Res. 37 (2007) 1215-1222, https://doi.org/ 10.1016/j.cemconres.2007.04.007.

[4] D.M. Mulenga, J. Stark, P. Nobst, Thaumasite formation in concrete and mortars containing fly ash, Cement Concr. Compos. 25 (2003) 907-912, https://doi.org/ 10.1016/S0958-9465(03)00136-7.

[5] P.M. Carmona-Quiroga, M.T Blanco-Varela, Prevention of sulfate-induced thaumasite attack: thermodynamic modeling in $\mathrm{BaCO}_{3}$-blended cement, in: A. Diouri, N. Khachani, M.A. Talbi (Eds.), Proceedings of the International Congress on Materials \& Structural Stability, Morocco, Rabat, November 2013, pp. 27-30.

[6] P.M. Carmona-Quiroga, M.T. Blanco-Varela, S. Martínez-Ramírez, B. Lothenbach, Thermodynamic modelling of sulfo-resistant cements with barium compounds additions, in: M.A. Rogerio-Candelera, M. Lazzari, E. Cano (Eds.), Science and Technology for the Conservation of Cultural Heritage, Taylor \& Francis Group, London, 2013, pp. 287-290.

[7] P.M. Carmona-Quiroga, M.T. Blanco-Varela, Use of barium carbonate to inhibit sulfate attack in cements, Cement Concr. Res. 69 (2015) 96-104, https://doi.org/ 10.1016/j.cemconres.2014.12.006.

[8] P.M. Carmona-Quiroga, S. Gismera-Diez, S. Martínez-Ramírez, N. Husillos Rodríguez, M.T. Blanco-Varela, Developing new sulfate-resistant cements: a BaCO3 approach, in: Caijun Shi, Yan Yao (Eds.), Proceedings of the 14th International Congress on the Chemistry of Cement, Beijing, China, October 2015, pp. 13-16.

[9] Y. Su, X. Wei, J. Hunag, Y. Wang, X. He, X. Wang, B. Ma, Use of Different Barium Salts to Inhibit the Thaumasite Form of Sulfate Attack in Cement-Based Materials vol. 31, J. Wuhan Univ. Technol.-Mat. Sci. Edit, 2016, pp. 361-366, https://doi. org/10.1007/s11595-016-1376-x.

[10] C. Xiong, W. Li, L. Jiang, W. Wang, Q. Guo, Use of grounded iron ore tailings (GIOTs) and $\mathrm{BaCO}_{3}$ to improve sulfate resistance of pastes, Construct. Build. Mater. 150 (2017) 66-76, https://doi.org/10.1016/j.conbuildmat.2017.05.209.

[11] X. Wen, Z. Zhang, Y. Cai, L. Feng, T. Qiu, Impact and improvement of crushed tuff sand on sulfate resistance of cement concrete at low temperature, J. Mater, Civ. Eng. 30 (2018) 5018004, https://doi.org/10.1061/(ASCE)MT, 19435533.0002457.

[12] Properties and applications of witherite, Nature 146 (1940) 457-458, https://doi. org/10.1038/146457d0.

[13] D.R. Lide, CRC Handbook of Chemistry and Physics, 86th ed., CRC Press, Taylor and Francis Group, USA, 2005.

[14] C.A. Johnson, N.M. Piatak, M.M. Miller, M. M, Barite (barium), in: K.J. Schulz, J. H. DeYoung, J. H, R.R. Seal II, D.C. Bradley (Eds.), Critical Mineral Resources of the United States-Economic and Environmental Geology and Prospects for Future 
Supply:, U.S. Geological Survey Professional Paper 1802, 2017, pp. D1-D18, https://doi.org/10.3133/pp1802D.

[15] H. Choudhury, R. Cary, Barium and Barium Compounds, Concise International Chemical Assessment Document 33, World Health Organization, Geneva, 2001.

[16] S. Haruehansapong, T. Pulngern, S. Chucheepsakul, Effect of nanosilica particle size on the water permeability, abrasion resistance, drying shrinkage, and repair, Ann. Mater. Sci. Eng. 2017 (2017) 4213690, https://doi.org/10.1155/2017/ 4213690.

[17] K. Sobolev, Nanotechnology and nanoengineering of construction materials, in: K. Sobolev, S.P. Shah (Eds.), Nanotechnology in Construction, Springer, 2015, pp. $3-13$.

[18] A. Folli, $\mathrm{TiO}_{2}$ Photocatalysis in Portland Cement Systems: Fundamentals of Self Cleaning Effect and Air Pollution mitigation, Thesis, University of Aberdeen, 2010

[19] Y. Reches, K. Thomson, M. Helbing, D.S. Kosson, F. Sanchez, Agglomeration and reactivity of nanoparticles of $\mathrm{SiO}_{2}, \mathrm{TiO}_{2}, \mathrm{Al}_{2} \mathrm{O}_{3}, \mathrm{Fe}_{2} \mathrm{O}_{3}$, and clays in cement pastes and effects on compressive strength at ambient and elevated temperatures, Construct. Build. Mater. 167 (2018) 860-873.

[20] J. Foldyna, V. Foldyna, M. Zelenák, Dispersion of carbon nanotubes for application in cement composites, Process Eng. 149 (2016) 94-99.

[21] M.T. Blanco-Varela, P.M. Carmona-Quiroga, I.F. Sáez del Bosque, S. MartínezRamírez, Role of organic admixtures on thaumasite precipitation, Cement Concr. Res. 42 (2012) 994-1000.

[22] D.S. Jayakrishnan, 5 -Electrodeposition: the versatile technique for nanomaterials, in: V.S. Saji, R. Cook (Eds.), Corrosion Protection and Control Using Nanomaterials, Woodhead Publishing Limited, 2012, pp. 86-125.

[23] J.-S. Ryu, N. Otsuki, Crack closure of reinforced concrete by electrodeposition technique, Cement Concr. Res. 32 (2002) 159-164.

[24] B. Han, L. Zhang, J. Ou, Self-Healing concrete, in: B. Han, L. Zhang, J. Ou (Eds.), Smart and Multifunctional Concrete toward Sustainable Infrastructures, Springer Nature Singapore Ltd, 2017, pp. 117-155.

[25] G. Fajardo, A. Cruz-López, D. Cruz-Moreno a, P. Valdez, G. Torres, R. Zanella, Innovative application of silicon nanoparticles (SN): improvement of the barrier effect in hardened Portland cement-based materials, Construct. Build. Mater. 76 (2015) 158-167.

[26] D. Alonso Domínguez, Estudio de la variación de la morfología y las propiedades microestructurales de materiales base cemento con adiciones de sílice de distinta granulometría, PhD Thesis, Complutense University of Madrid, Madrid, 2015.

[27] J.F. Fernandez, P. Leret, A. Moragues, E. Reyes, J.C. Galvez, E. Sánchez, D. Alonso, I. Alvárez, Method for producing a cementitious composite, and long-life micro/ nanostructured concrete and mortars comprising said composite, WO2017051052 (A1) (2017).

[28] M.A. de la Rubia, E. de Lucas-Gil, E. Reyes, F. Rubio-Marcos, M. Torres-Carrasco, J. F. Fernández, Viability study of a safe method for health to prepare cement paste with simultaneous nanometric functional additions, Adv. Mat. Sci. Eng 5 (2018) $1-13$.

[29] I. Lorite, J.J. Romero, J.F. Fernandez, Study of the nanoparticle/microparticle powder systems by dry dispersion, Cer. Int 39 (2013) 1631-1637.

[30] D.L. Kantro, Influence of water-reducing admixtures on properties of cement paste-a miniature slump test, Cem. Concr. Aggregates 2 (1980) 95-102.

[31] J.S. Raucci, R.T. Cecel, R.C.O. Romano, R.G. Pileggi, V.M. John, Effect of mixing method on the mini-slump spread of Portland cement pastes, IBRACON Struct, Mat J. 11 (2018) 410-431, https://doi.org/10.1590/s1983-41952018000200010.

[32] Z. Tan, S.A. Bernal, J.L. Provis, Reproducible mini-slump test procedure for measuring the yield stress of cementitious pastes, Mater. Struct. 50 (2017) 235, https://doi.org/10.1617/s11527-017-1103-x.

[33] ASTM, C1012/C1012M-18b, Standard Test Method for Length Change of Hydraulic- Cement Mortars Exposed to a Sulfate Solution, ASTM International, West Conshohocken, PA, 2018.

[34] UNE-EN 196-1, Methods of Testing Cement - Part 1: Determination of Strength, AENOR, Madrid, 2018.

[35] I. Mehdipour, K.H. Khayat, Effect of particle-size distribution and specific surface area of different binder systems on packing density and flow characteristics of cement paste, Cement Concr. Compos. 78 (2017) 120-131, https://doi.org/ 10.1016/j.cemconcomp.2017.01.005.

[36] P. Hawkins, P.D. Tennis, R.J. Detwiler, The Use of Limestone in Portland Cement: A State-Of-The-Art Review, EB227, Portland Cement Association, Skokie, Illinois, USA, 2003.

[37] V. Rahhal, R. Talero, Early hydration of Portland cement with crystalline mineral additions, Cement Concr. Res. 35 (2005) 1285-1291, https://doi.org/10.1016/j. cemconres.2004.12.001.
[38] K. Vance, M. Aguayo, T. Oey, G. Sant, N. Neithalath, Hydration and strength development in ternary portland cement blends containing limestone and fly ash or metakaolin, Cement Concr. Compos. 39 (2013) 93-103, https://doi.org/10.1016/j. cemconcomp.2013.03.028.

[39] Gyu Don Moon, Sungwoo Oh, Sang Hwa Jung, Young Cheol Choi, Effects of the fineness of limestone powder and cement on the hydration and strength development of PLC concrete, Construct. Build. Mater. 135 (2017) 129-136, https://doi.org/10.1016/j.conbuildmat.2016.12.189.

[40] C.A. Utton, E. Gallucci, J. Hill, N.B. Milestone, Interaction between BaCO3 and OPC/BFS composite cements at $20^{\circ} \mathrm{C}$ and $60{ }^{\circ} \mathrm{C}$, Cem, Concr. Res. 41 (2011) 236-243, https://doi.org/10.1016/j.cemconres.2010.11.006.

[41] S.K. Ouki, C.D. Hills, Microstructure of Portland cement pastes containing metal nitrate salts, Waste Manag. 22 (2002) 147-151, https://doi.org/10.1016/S0956053X(01)00063-0.

[42] D. Marchon, R.J. Flatt, Mechanisms of cement hydration, in: P.-C. Aïtcin, R.J. Flatt (Eds.), Science and Technology of Concrete Admixtures, Woodhead Publishing, 2016, pp. 129-145, https://doi.org/10.1016/B978-0-08-100693-1.00008-4.

[43] L. Wadsö, F. Winnefeld, K. Riding, P. Sandberg, Calorimetry, in: K. Scrivener, R. Snellings, B. Lothenbach (Eds.), A Practical Guide to Microstructural Analysis of Cementitious Materials, CRC Press Taylor \& Francis Group, Boca Raton, Florida, 2016, pp. 37-74.

[44] E. Berodier, K. Scrivener, Understanding the filler effect on the nucleation and growth of C-S-H, J. Am. Ceram. Soc. 97 (2014) 3764-3773, https://doi.org/ 10.1111/jace.13177.

[45] P.M. Carmona-Quiroga, S. Martínez-Ramírez, M.T. Blanco-Varela, Thermodynamic stability of hydrated Portland cement phases in the presence of barium carbonates, in: Proceedings of the 13th International Congress on the Chemistry of Cement, Madrid, 2011.

[46] R. Gabrovšek, T. Vuk, V. Kaučič, The preparation and thermal behavior of calcium monocarboaluminate, Acta Chim, Slov 55 (2008) 942-950.

[47] B. Lothenbach, P. Durdziński, K. De Weerdt, Thermogravimetric analysis, in: K. Scrivener, R. Snellings, B. Lothenbach (Eds.), A Practical Guide to Microstructural Analysis of Cementitious Materials, CRC Press Taylor \& Francis Group, Boca Raton, Florida, 2016, pp. 177-211.

[48] K. Rajczyk, W. Nocun-Wczelik, The dicalcium orthosilicate and its hydraulic activity examination by DTA-TG and calorimetric methods, J. Therm. Anal 45 (1995) 931-936, https://doi.org/10.1007/BF02547460.

[49] R. Roychand, S. De Silva, D. Law, S. Setunge, High volume fly ash cement composite modified with nanosilica, hydrated lime and set accelerator, Mater. Struct. 49 (2016) 1997-2008, https://doi.org/10.1617/s11527-015-0629-z.

[50] P. Pipilikaki, M. Beazi-Katsioti, The assessment of porosity and pore size distribution of limestone Portland cement pastes, Cons. Build. Mat 23 (2009) 1966-1970, https://doi.org/10.1016/j.conbuildmat.2008.08.028.

[51] S. Gismera-Diez, B. Manchobas-Pantoja, P.M. Carmona-Quiroga, M.T. BlancoVarela, Effect of $\mathrm{BaCO}_{3}$ on $\mathrm{C}_{3} \mathrm{~A}$ hydration, Cement Concr. Res. 73 (2015) 70-78, https://doi.org/10.1016/j.cemconres.2015.03.009.

[52] K. De Weerdt, M. Ben Haha, G. Le Saout, K.O. Kjellsen, H. Justnes, B. Lothenbach, Hydration mechanisms of ternary Portland cements containing limestone powder and fly ash, Cement Concr. Res. 41 (2011) 279-291, https://doi.org/10.1016/j. cemconres.2010.11.014.

[53] T. Schmidt, B. Lothenbach, M. Romer, J. Neuenschwander, K. Scrivener, Physical and microstructural aspects of sulfate attack on ordinary and limestone blended Portland cements, Cement Concr. Res. 39 (2009) 1111-1121, https://doi.org/ 10.1016/j.cemconres.2009.08.005.

[54] A. Baldermann, M. Rezvani, T. Proske, C. Grengg, F. Steindl, M. Sakoparnig, C. Baldermann, I. Galan, F. Emmerich, F. Mittermayr, Effect of very high limestone content and quality on the sulfate resistance of blended cements, Construct. Build. Mater. 188 (2018) 1065-1076, https://doi.org/10.1016/j. conbuildmat.2018.08.169.

[55] Y. Esen, B. Yilmazer, Investigation of some physical and mechanical properties of concrete produced with barite aggregate, Sci. Res. Essays 5 (2010) 3826-3833. https://www.researchgate.net/publication/267198092.

[56] N.B. Tiburzi, J. Garcia, T. Drimalas, K.J. Folliard, Sulfate resistance of portlandlimestone cement systems containing greater than $15 \%$ limestone, Cement Concr. Compos. 100 (2019) 60-73, https://doi.org/10.1016/j.cemconcomp.2019.03.024.

[57] S. Sahu, S. Badger, N. Thaulow, Evidence of thaumasite formation in Southern California concrete, Cement Concr. Compos. 24 (2002) 379-384, https://doi.org/ 10.1016/S0958-9465(01)00090-7.

[58] P.M. Carmona-Quiroga, M.T. Blanco Varela, Resistance to thaumasite sulfate attack in $\mathrm{BaCO}_{3}$-bearing cement pastes and mortars, Cement Concr. Res. (2020) 106052, https://doi.org/10.1016/j.cemconres.2020.106052. 